University of Rhode Island

DigitalCommons@URI

Open Access Master's Theses

1963

\title{
The Comparative Cardiovascular Effects of Substituted Cyclohexane Derivatives
}

John Charles Smith

University of Rhode Island

Follow this and additional works at: https://digitalcommons.uri.edu/theses

\section{Recommended Citation}

Smith, John Charles, "The Comparative Cardiovascular Effects of Substituted Cyclohexane Derivatives" (1963). Open Access Master's Theses. Paper 920.

https://digitalcommons.uri.edu/theses/920

This Thesis is brought to you for free and open access by DigitalCommons@URI. It has been accepted for inclusion in Open Access Master's Theses by an authorized administrator of DigitalCommons@URI. For more information, please contact digitalcommons-group@uri.edu. 
THE COMPARATIVE CARDIOVASCULAR HFTRCTS OP SUBSTITUNED CYCLOHEXANE DRRTVATIVES

BY

Jotn crapuss SMTYH, JR.

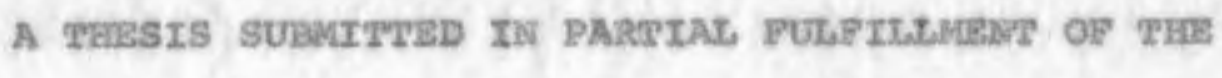
REOUTRBAENTS BOR THE DEGRBE OF

MASTER OF SCTENCE

IN

PHARMACOZOGY

UATVERSTTY OP REODIS TELAWD

1963 
MASTER OF SCIeNCE THESIS

or

JOHN CHARLES SMITH, JR.

Approved:

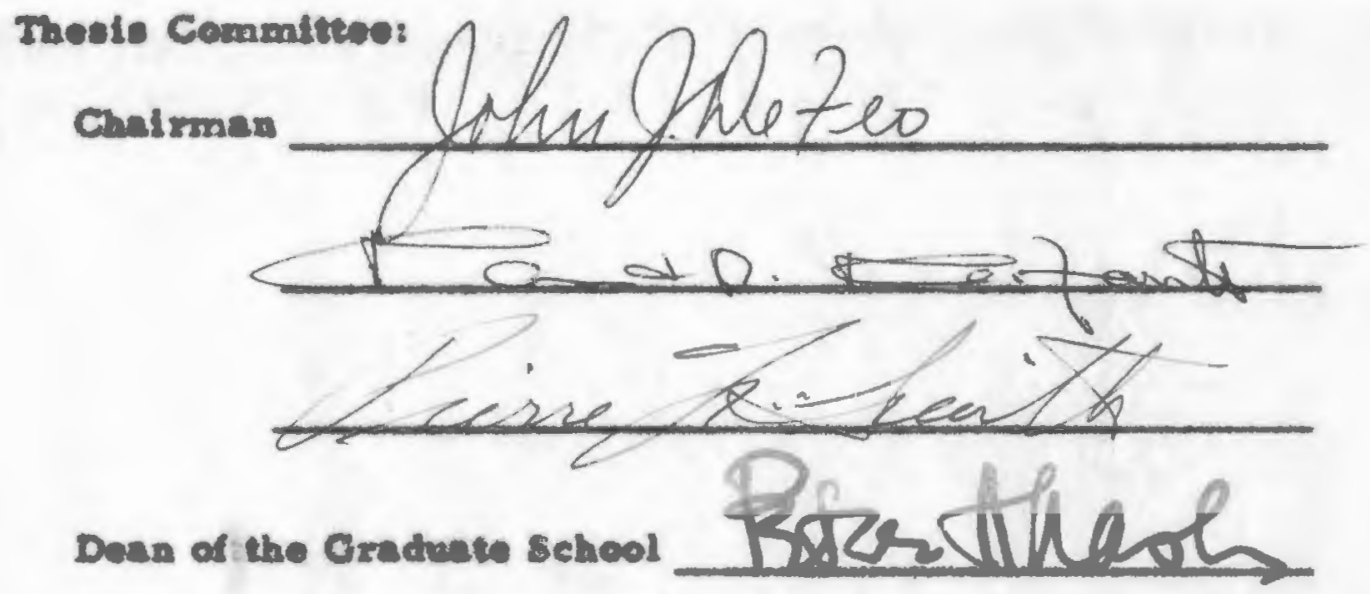

UNIVERSITY OF RHODE ISLAND

2363 


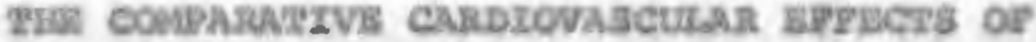

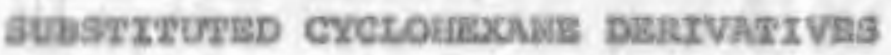

Dy

Jorw CIMnuns surra, JR.

\begin{abstract}
ABSTRACP

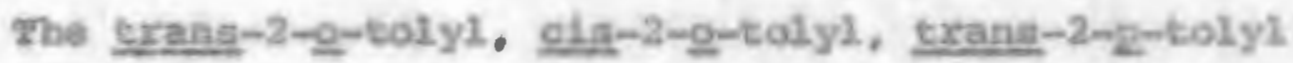
and $\mathrm{els}-2-\mathrm{g}-\mathrm{toly}$ derivativas of cyolohescylamine hydrochlorido and six other cyclohexane derivatives were tested for their effects on intact anesthetized rats. Isolated rat atria. Lsolated guinea pig hearts, isolated guinea pig ixteatinea, and intact anesthetized cats. Most of these compounde produced effecta on the cardiovaseular systee and on the satil intestine in varying degrees.

Trans-2-0-tolylcyclohexylanine hydrochloxide ves the nost potent of the cyclohexylasise series tested. Of the six other compounds teated. 2-o-boly2cyclohexen-2-one (204) wa the most potent in its cardiovascular effects.

Studias indicate that trans-2-0-tolyleyclohexylamine hydroctulorlde does not produce toxic effects in dosse which ellalt its cardiovasculer actions.
\end{abstract}




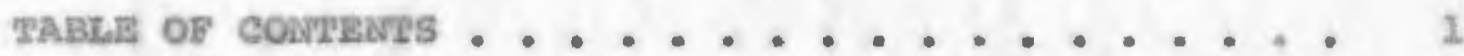

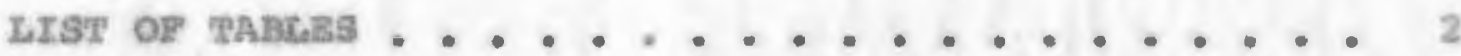
LIST OF IHUSTragtons ... . . . . . . . . . . . 5 I. INTRODUCTION . . . . . . . . . . . . . . 6 I. REVTER OR IETERATURIS . . . . . . . . . . . . 7 II. MUS IMVESTIGATZON . . . . . . . . . . . . . 10 A. ORJectgVis ..................... 10 B. THE COMPOUNDS ................. 10 C. ANTMALS USED ........ . . . . . . . . . 13 D. EXPERTMBNFAL RROCEDURaS ALD RESULTS . . . - 13 IV. DIScusston . . . . . . . . . . . . . . . 63 v. sumuar ......................... 68 VI. conctuston ..................... 70

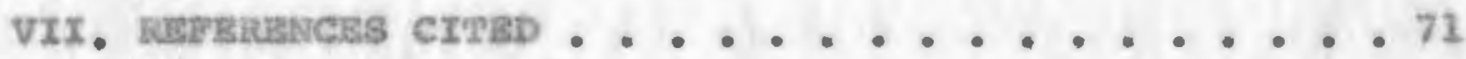
VIII. Acrarowredganariv . . . . . . . . . . . . 72 


\section{LTaF OP TABLES}

2ants

Page

I Effecta of tyan3-2-2-tolyleyrelohexylandne hydxo-

chloride on the blood greasure of rata . . . . . 16

II Bffects of eig-2-2-toly2 cycloheocylankno hydro-

chloride on the blood proseure of rata ....... 27

IxI Bffects of terans-2-D-toly2 fycloherylealne hydxochloride on the blood presaure of rats . . . . . 10

IV ECfects of gis-2-o-tolylgyelohecylanind hydro-

chloride on the blood preasure of rats ....... 19

V Ifgects of eubistituted cyclobescylantne hydro-

chloride desivatives on the blood pressure of eata - 20

Vx A comperieon of the BDso (hypotensive) of substituted myolohesylamine hydrochloride derivatives tested on

the blood presarare of rats .............. 21

VII A eouparimon of tha efkects of substituced ayalobecylamine hydrochloride derlvatives on the blood preasure of sats and cats . . . . . . . . .

VIII Iffects of trans-2-2-tolylcyolohorylandne hydxo-

chloride on the isolated guinas plg heart . . . .

Ix Bffectu of eis-2-p-tolylcycloherylanine bydro-

chloride on the isolated guinea plg haart.

$x$ Btfacts of trans-2-o-tolylcyelohoxylanine iydtoehloride on the isolated guinea pig beart. . . .

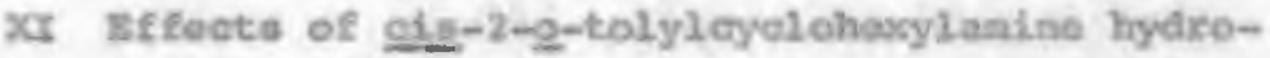
chlortde can the leolated guinea pig hoset . . . 
TARS

Page

XII BEtecta of polybthylenegyeol 400 on the isolated gulnea plg hoste ..............

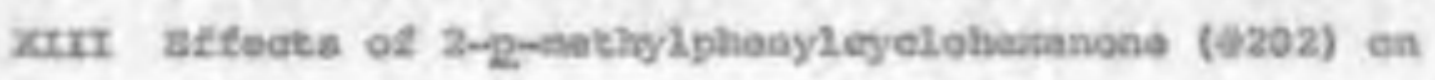
tho inolated guinas pig heart .......... 32

xcrV ketects of 2-2-eethylphenylcyclohaicanone (v203) on the seolated guines ple heart . . . . . . . . 33

icy zefaets of 2-2-tolyleyelohesen-2-one (e204) on the ibolated guina plg boart. . . . . . . . . 34

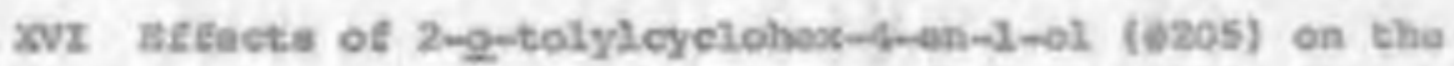
isolated guineh pig hoart ........... 35

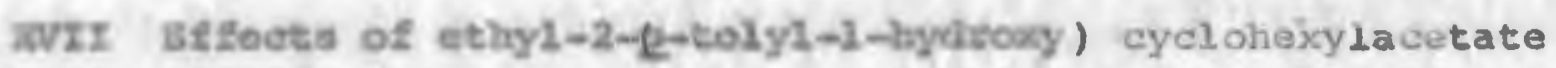
(iizos) on the isolated guinea pig heare . . . . . 36

XyrII The coxparasive effocts of adbstituted eyelohescylninine hydrochloride derivativee on the isolated guinea pig

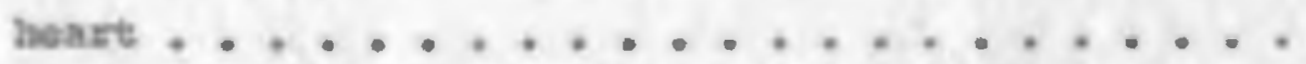

2crx comparative offocts of the miedellanoons aubatituted gyelohosane derivativea on the 1solated gainoa pig hoart. ....................

yox ifloots of trana-2-2-tolyleyelohexylanine hydrochloride on the lsolated rat atris . . . . . . .

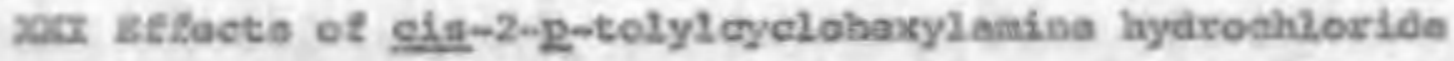
on the daolated rat atria . . . . . . . . .

xoxzI Bffeats of trans-2-2-toly2 cyelohesglanine hydrochloxide on the loolated rat atria ............

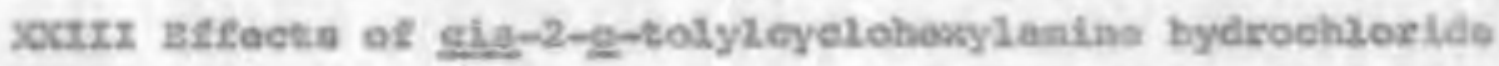
on the 1solated rat atria . . . . . . . . .

icrrv sefecte of polyethylenoglycol 400 on the daolated zat: atria .................... 


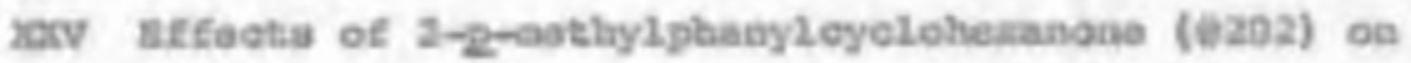

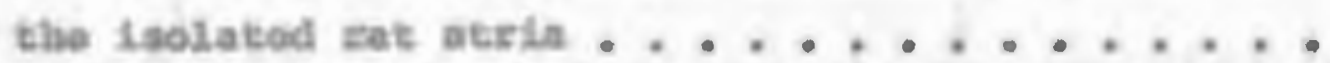

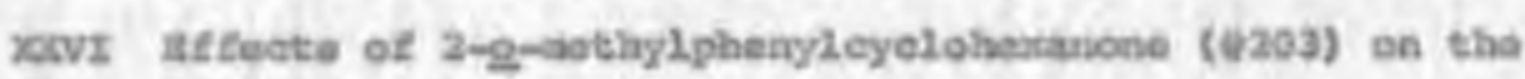
isolated rat atria ..............

xovx sefecta of 2-o-tolyleyelohesen-2-one (6204) on the

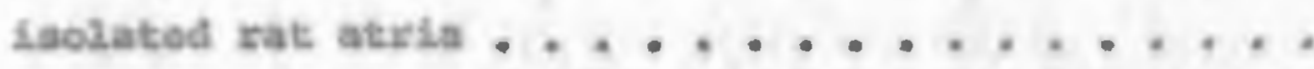

zocvxx Befacts of 2 -qutolyleyelohest-4-an-l-ol (U20s) on the isolated rat ateria ...................... 50

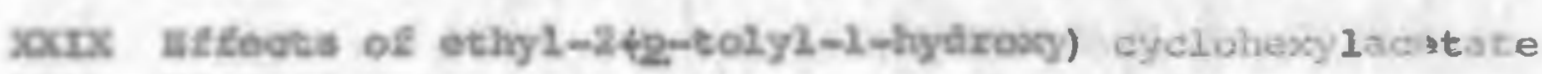
(1206) an the daolated rat atria . . . . . . .

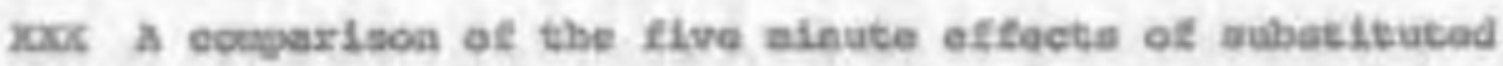
cyelohexylanino hydrochoricle derivativen on the rat

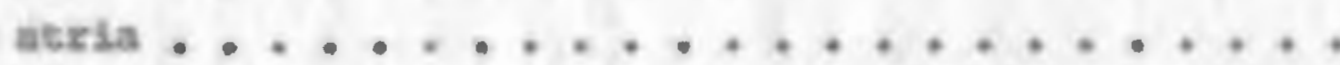

mocx Bffoots of texang-2-2-tolyleyclohoxylandino hydrochloride on the trolated guines pig anal1 intestine . . .

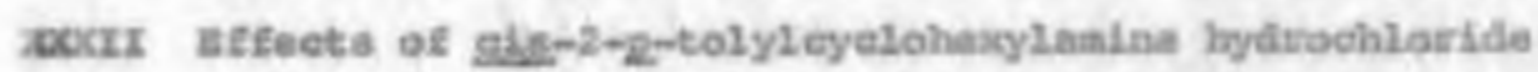
on the doolated guinea plg salz intentino . . . .

xcocrxz sefects of trang-2-2-tolyleyolohesylamine hydrochlotide oe the isolatad guinea gig sall intastine . . . .

acocrv Bffects of c1e-2-0-tolylcyelohaxylandne Mydrochlorido on the isolated guines pig anall Intestine . . . . $5 a$ socy sefocts of polyethyleneglyeol 400 on tha 1 solared guinea plg anall inteotine............

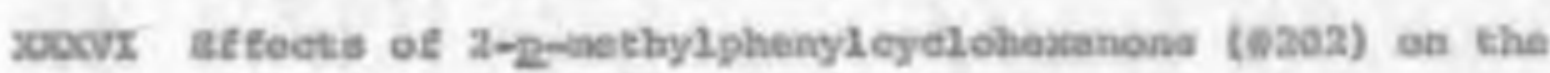
Lalated guinah plg anal1 Iateatine . . . . . .

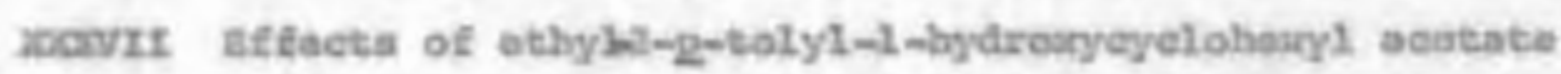
(\$206) on the isolated golnee pig amall inteestine ... 


\section{LIST OP IxLUSTRAgrows}

rig.

Page

1. Cyeloherylaaine Gerivatives ............ 11

2. Miscellaneous cycilohescane derivatives . . . . . 12

3. A comparison of the hypotensive effects produced by substituted oyelohescylanine hydrochloride derivatives

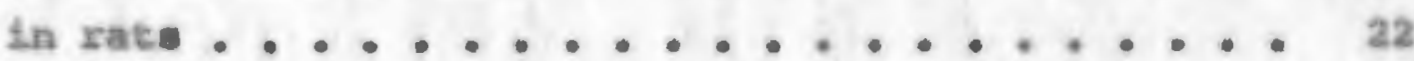

4. The effect of 2-o-tolyleyclohexen-2-one (M204) (1.13ig) on isolated rat atria .............

5. The effect of ethyl-2te-tolyl-1-laydroxy) eyclohaxylacetate (a206) (3.6ag) on laolated rat atria . . . 45

6. The effect of trans-2-0-tolyleyclohesylauine hydrochloride (2.98ung) on isolated guineh pig intestino . .62

7. The effect of sis-2-2-tolyleyelohexylanaine hydrochloride (0.48ag) on isolated guinea pig inteatine . 62 


\section{IKFRODUCRION}

Previous studies bave shown that gyclohosane and cyclohexanol derivatives actively affect the eardiovascular systean. Cyoloherane and cyclohevanol dexivatives have loan shown to be eapable of producing cardioplegia in dogs undergoing cardlopulaonary bypass. Correlations were shown by 3mooklex (1962) between the iscmer of cyclohescanol and it: degrae of activity.

New oyelohexylamine lrydrochloride derivatives of cyclohescane were prepared to test this dass of conpounda on the cardiovascular system, to determine the existence of structure-activity rolationahips, and to assess their ability to produce cartioplegia. These compounda were also tested For theix effeets on isolated smooth auscle to determine the presence of othor aotions by this series. 


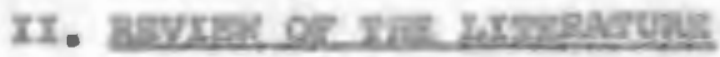

During the past Low yoars tha cyelobexane group has boen includod in a nurber of conporenda which have bean investigated for theix poasibie use as druga. Cyelohexana and ita many derivatives have boon extennively inveatigated tor industrial use, llowsver, fow of these dompounds have been bestee for pharmacologleal aetions,

ladtrle at al. (1959) raported that trans-2-g-toly1eyclohesanol prodveed mechanteal axzest in the haarts of experivantal anisals. valson et a1. (2959) also investigated this ocmpound and ruported sinstar findings.

Snooklex and DeFeo (1962) extensivaly invoetigated cyclohexana and substituted 2-ary 1 dexivatives of eyolohexanol and found that these oompounds actively affoct the caxasovasculat syaten. The compounde teated vexe thom to be capable of lowering the blood prossure of intact rats and depseasing myocardial contrectility of ieolated and intaot hearts. Sulfstitution of chlorophenyl or toly 1 groups in the 2 -aryl position of the ayalohescanol moloty was found to incxense the hypotanaive affeat from six to forty tines. $\mathrm{Ml1}$ in the sertea

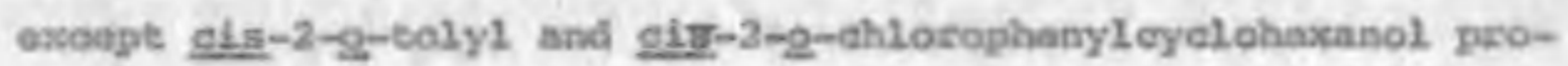
duced carblac arrest of laoleted perfused guinea pig hoarts. Once again. tho aubstitution of thase groups increasod the cardio-inhibitory activity of cyclobescanol from four to twonty timas. Ixana-2-Q Cexivatives ware the dost active on the Lalated guinea pig bearts. Atrial studies conducted shoved that the depresant action of trang-2-o-tolyldyolohescasol was enteagonimod by oaleium. 
dupublished work of Bapokler (1961) showed that trans-2-2-tolyleyclohexanol ahd trans-2-0-chloroghanyloyclobexanol also producod cardioplogia In doga undergolng cardiopulmonary bypase. In soise of theso experinenta, the nornal hoart bate roturned following the arrout.

othar coapounds eontaining the cyclohencyl group have beon inveatigated. Graifanatedn ot a. (195a) studied 1-12phanylcyelohestyd) piporidine hydrochlorlute (Sernyl) for usa in anortheain. Mea glvas intxavenoualy to huran patients, the aubatance produesd gogd anblgenia but dil not relax matoles. ithen dosas laxges thai nortial vexe given, convulsions oceuerad Initially. The blood prensure and the resplration both increased silghtiy.

Lear et al. (1959) have tested n-ethyl-1-phenyleycloheorylanine monolzydrochloride (cyelobasasins) and Sarayl elinically as analgosie agonts for wes in anjor muxgery and found that thoy produco blockade of aensory impulnoa without produelng sleep. Howaver, paychie diaturbances resulted tollowing the wae of Sernyl. Heither oodpound depreased bloca presuure or resplxation, The alte of ation of these drogr was not found. Caxdiac rhythm was unalfected. N1as, thexe was an increase in ralivation.

Luby at al. (1959) studied the paychie affeets of 1-(1-pheny 1eyelohory1) piperidine anohydrochloride and found that the drug produced a psychopathology sinilar in natura to prinary symptons of the schibophrenid psocesa. The tho derivatives, 2-(1-phenyloyclolvexyl) piperidine 
monohydrochloride and n-ethyl-1-phenyleycioherrylanine monohydrochloride have been studied by Adey and Dunlop (1960). These compounds were found to interfere with a learned appoach in a $\mathrm{T}$-naze situation for periods of up to twenty-foux hour following interperitoneal injection in cats. Electroencephalograph records shew that an interference with discharge from the hippoeanpal structures was produced during the period in which these derivatives were active. 


\section{THE. THVESTIGNTCO}

A. ODJecervis

sibetituted eyelohexylanine bydrochloride dexivatives and misoellaneous cyolohosane derivativas have been recent1y syathesizod, Ifo reporte vare found in tha 1iterature of their actiond, and this imveatigation vas undertaken to deternine their effecta on tha cardiovascular systen and on othex systeas, and eo deterwine wathex strecture activity relations can be established tor the 2-aryl leceners of eyelohexylanine hydrochloride. Thia investigation includes:

1. The acreening of the earpounds for thaix effects on the andmals or tiesues used.

2. The attergt to deteraine abchandsme by Mhlch these ecrpounds produce their affects.

B. THE courpouids

The dawpounda usod havo beex prepared by De. MaLin C. Ifoiteide of the Departant of Pharasceutical Chenietry. Dolvoraity of ifashington, College of Pharnacy, Beattle, Washington. Tha cyelohoxylamine mydroobleride snits (FIg. 1) are seadily solvble and agueous solutions of thone oorivatives ware used throughout the inveatigation. Al1 the othex coipounds (Fig. 2) were abluble in polyethylemeglycol (PRe) 400. The polyethylaneglyeol solutions of

Pig. 1 Cyclohexylandine derivatives

Fig. 2 nisoellanedoas cyelohexane derivative 
FIg. I - CYCLOHEXYLAMINE HXDROCHLORIDE DERIVATIVES

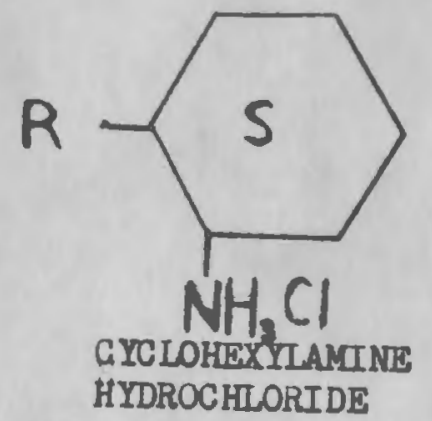

B
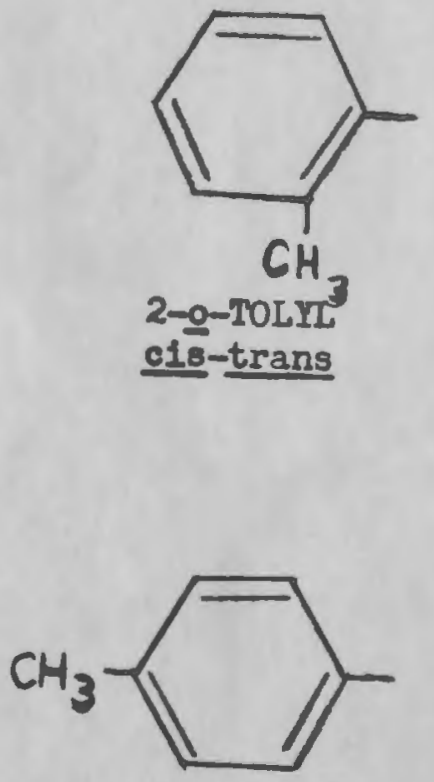

2-p-TOLYL cig-trens 

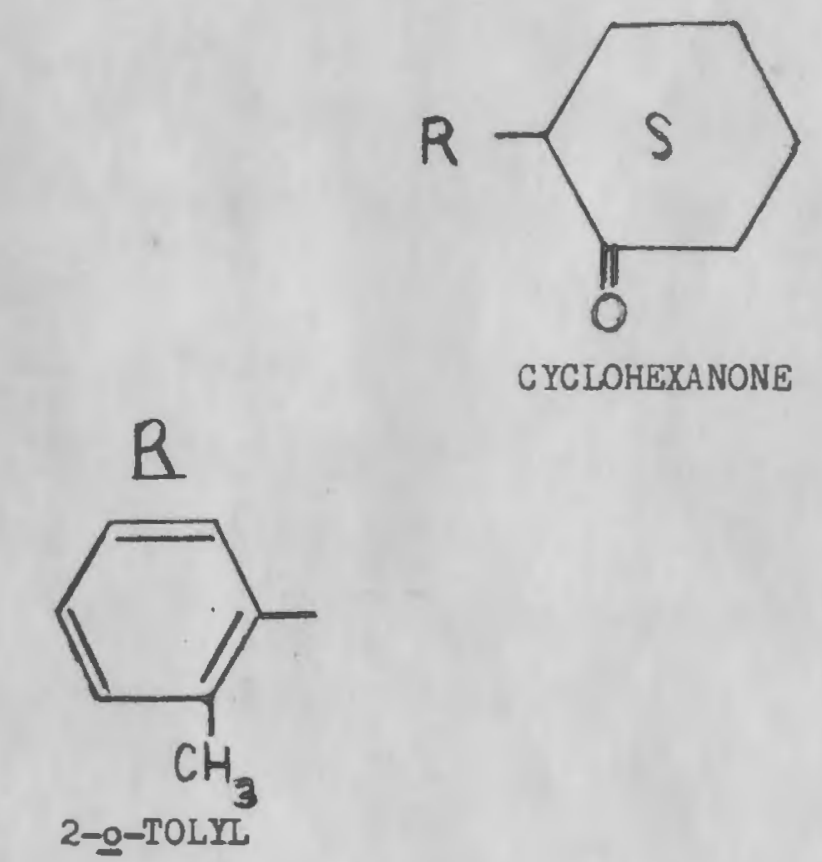

CYCLOHEXANONE
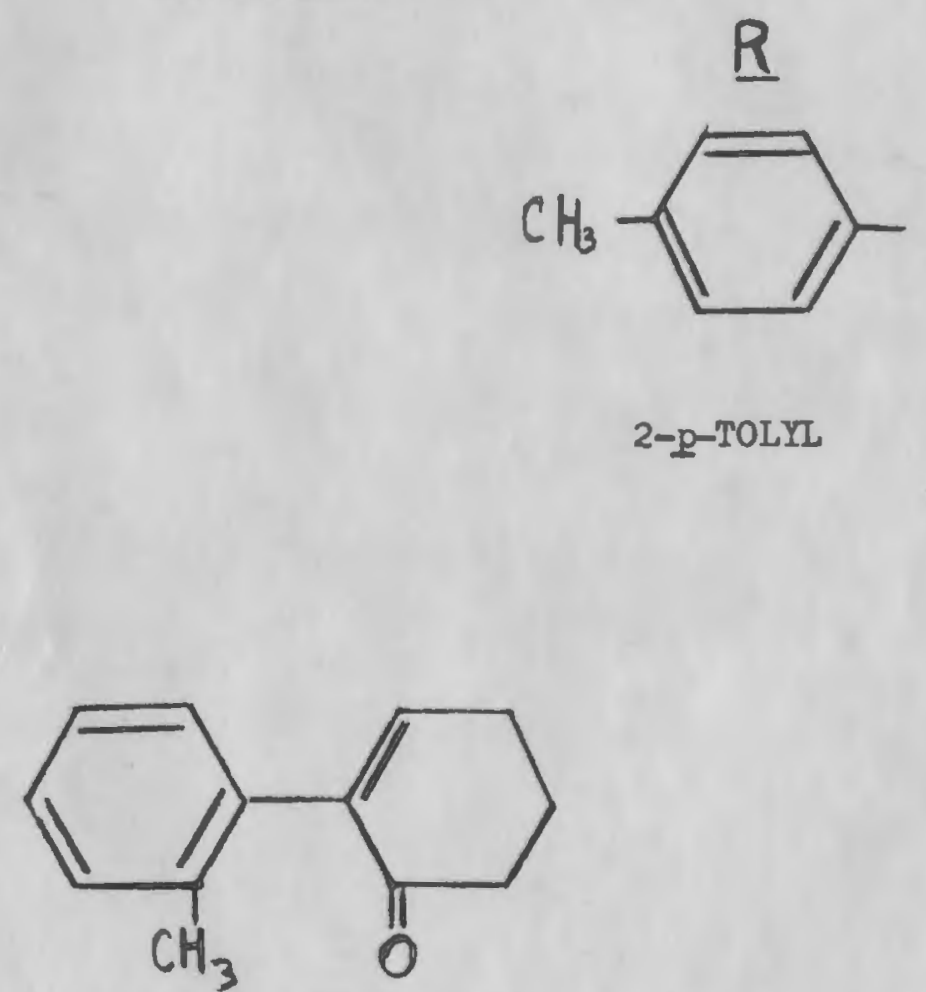

2-O-TOLYI CYCLOHEXEN-2-ONE

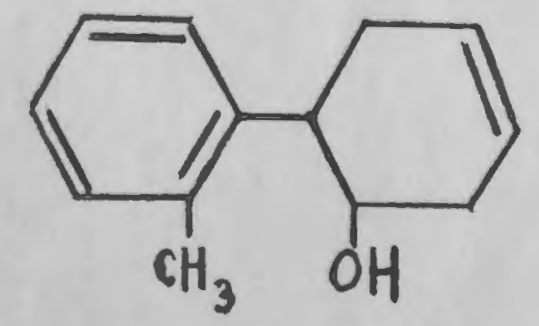

2-O-TOLIL CYCLOHEX-4-EN-1-OL

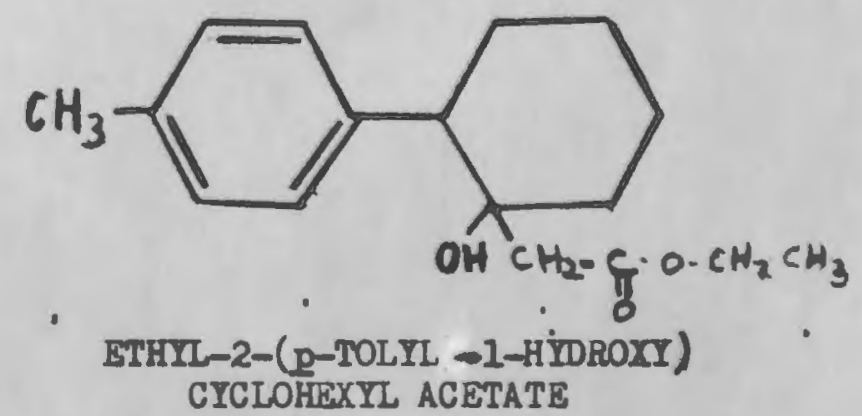


these conpounds were used thxoughout the investigation.

c. Amrounas USigD

1. Rata - Albino rats of the Wistar (MW-2) strain vere eaployed in part in the investigation.

2. Guinea pigs - The guinea pigs ware of a heterogenous group.

3. Cata - The Caty were of a heterogenou group.

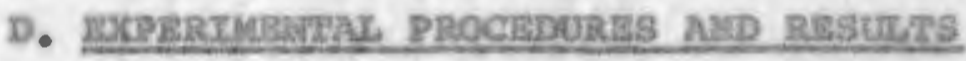

This inveatigation was divided into five sections:

1. The effects of the cyelohorylaudne derivatives on the blood pressure of intaet anesthetized xats and cats.

2. The effects of all of the compounds on isolated guinea pig atria.

3. The effects of all of the derivatives on isolated perfused guinea pig hearts.

4. The effects of all of the derivatives on isolated anald intestinal stripu. 
1. Sftacta of Bubstituted Cyclohersy araine Eydrochloride Profugta on the Blood Pressure of Rats and Cats

a. Bxpezimantal Procedures

The blood pressure of male albino rata vas recorded using dixect cannulation of the enrotid artery. A mercury manometer, gonnected Via a sluid bridje of wodium chloride 0.9 pez cont to the cannula, was atilized. Recordinge vexe ande by a glasa writing lever on asolked kyaograph paper. The cannula was fllled with heparin to prevent the blood from eloteing.

The animala vere anesthetirod with sodiun pentobnrbital, $39 \mathrm{mg} . / \mathrm{kg}$. (IP). The trachea was chnnulated to allow unobatrweted respiration. Injection of the Arugs was made into either fomoral vein, by a noodle permanently securod to the vesael.

When the blood prasoure atudies ware sade ualing eats, the blood presaure vas recorded on a phystograph, using a callbrated stathaa tranoducer.

Allowing auftielent recovery Erom the previou injection, as many as three lajeotions wore lade inte each rat. The usual xesponse vas an fmodiate drop in the blood prensure, often follonved by a gradual zLes. At least twanty ninutea were allowed between infectione of the drug to allow the bloal pressure to etabilize.

The observations sade in these atuales ineludes

1. Tha per cent dxop in blood preasure produced by the oompound. 
2. The period of time required for the blood pressure to seturn to 95 per cent of its hormal value prior to injeotion of the drug.

S. Results

The resultis include the following:

1. The effects of substituted cyclohexylamine hydrochloride derivative on the blood pteseure of rats and cats. (rables $x$ to $v$ )

2. A comparison of the effeets of the several canpounda tested on the blood pressures. (Table VI, Fig. 3)

3. A comparison of the effects of selected aloses of the various eorapounds on the blood pressures of the rat and of the cat. (Table vir) 
Table $I$ gefects of trans-2-2-tolyleyclohescylaraine hydrochloride on the blood pressure of rats

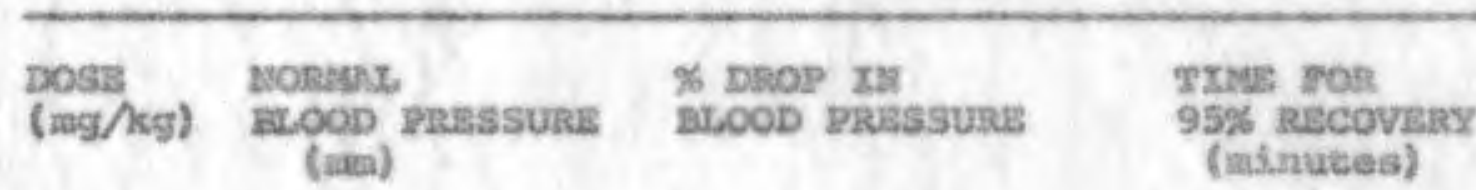

\begin{tabular}{rrrc}
\hline 6.0 & 150.0 & 33.3 & $\mathrm{n}$ \\
6.0 & 124.0 & 42.2 & 53.0 \\
12.0 & 100.0 & 52.0 & 34.0 \\
18.0 & 106.0 & 72.2 & 58.0 \\
24.0 & 153.0 & 70.6 & 30.0 \\
36.0 & 74.0 & $\mathrm{~B}$ & $\mathrm{3}$ \\
\hline
\end{tabular}

A incompleta recovery obtuined

8 andral died 
Table Ir Bffecto of cfs-2-p-tolyleycloherylanine hydrochloride on the blood pressure of rats

\begin{tabular}{|c|c|c|}
\hline (mosts $/ \mathrm{kg})$ & $\begin{array}{l}\text { MORELAL, } \\
\text { ELOOD PRESSURE } \\
\text { (ma) }\end{array}$ & $\begin{array}{l}\text { \% DROP IN } \\
\text { BLOOD PRESSURE }\end{array}$ \\
\hline
\end{tabular}

FIMER FOR

95\% RECOVERY (nimutes)

\begin{tabular}{rrcc}
\hline 6.0 & 206.0 & 45.3 & $\mathrm{~A}$ \\
5.0 & 117.0 & 39.3 & 20.0 \\
22.0 & 96.0 & 52.2 & 20.0 \\
16.0 & 92.0 & 54.3 & 9.0 \\
18.0 & 104.0 & 33.6 & 60.0 \\
18.0 & 96.0 & 44.0 & 3.0 \\
18.0 & 96.0 & $\mathrm{~B}$ & $\mathrm{~B}$ \\
18.0 & 54.0 & $\mathrm{~B}$ & $\mathrm{~B}$ \\
18.0 & 90.0 & 37.8 & $\mathrm{~A}$ \\
24.0 & 98.0 & 99.0 & $\mathrm{~B}$ \\
30.0 & 70.0 & $\mathrm{~B}$ & \\
\hline
\end{tabular}
A incomplete recovery obtained
B aniral aied 


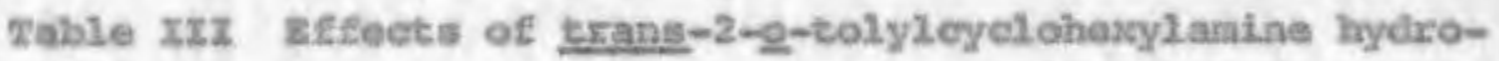
chloride on the blood pressure of rats

\begin{tabular}{|c|c|c|c|}
\hline $\begin{array}{l}\text { Doses } \\
\text { (ing/hg) }\end{array}$ & 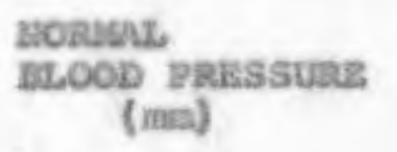 & $\begin{array}{l}\text { \% Davo In } \\
\text { BLOOD prussure }\end{array}$ & $\begin{array}{l}\text { TXaz FOR } \\
\text { 95\% Racovary } \\
\text { (minutas) }\end{array}$ \\
\hline 3.0 & 94.0 & 34.0 & 8.0 \\
\hline 6.0 & 116.5 & 48.9 & 66.0 \\
\hline 8.3 & 105.0 & 51.4 & 50.0 \\
\hline 9.0 & 100.0 & 42.5 & 33.0 \\
\hline 9.0 & 97.0 & 40.2 & A \\
\hline 9.0 & 135.0 & 54.8 & A \\
\hline 9.0 & 79.0 & 41.8 & $\mathrm{~A}$ \\
\hline 9.0 & 216.0 & B & B \\
\hline 12,0 & 120.0 & 76.7 & 23.0 \\
\hline 25.0 & 98.5 & 72.0 & 46.0 \\
\hline 28.0 & 91.0 & 74.2 & B \\
\hline 21.0 & 112,0 & 91.1 & 8 \\
\hline
\end{tabular}
A incouplete recovery obtained
B animal died 
Table IV Bftoets of cis-2-o-tolylcyclohexylamine hydrochloride on the blood pressure of rats

\begin{tabular}{|c|c|c|c|}
\hline $\begin{array}{l}\text { DOSE } \\
\text { ( } \mathrm{mg} / \mathrm{kg})\end{array}$ & $\begin{array}{l}\text { NORWAL } \\
\text { BLOOD PRESSURE } \\
\text { (min) }\end{array}$ & $\begin{array}{l}\text { \% DROP IVI } \\
\text { BUOOD PRBSSURB }\end{array}$ & $\begin{array}{l}\text { TIUR FOR } \\
\text { 95\% aEcoverikx } \\
\text { (minutes) }\end{array}$ \\
\hline 3.0 & 55.0 & 54.5 & 68.0 \\
\hline 3.0 & 97.0 & 38.2 & A \\
\hline 6.0 & 93.0 & 28.0 & A \\
\hline 9.0 & 94.0 & 25.5 & 80.0 \\
\hline 9.0 & 100.0 & 51.0 & 3.0 \\
\hline 12,0 & 69.0 & 53.6 & 3.0 \\
\hline 15.0 & 95.0 & 44.2 & 3.0 \\
\hline 1.5 .0 & 90.0 & 37.8 & A \\
\hline 28.0 & 148.0 & 56.8 & B \\
\hline 18.0 & 100.0 & 38.0 & A \\
\hline 18.0 & 90.0 & 42.2 & 40.0 \\
\hline 22.0 & 95.0 & 37.9 & 26.0 \\
\hline 21.0 & 111.0 & 73.9 & 80.0 \\
\hline 24.0 & 111.0 & 72.9 & 90.0 \\
\hline 27.0 & 89.0 & 75.3 & $\pi$ \\
\hline 30.0 & 102.0 & B & $\mathrm{B}$ \\
\hline 33.0 & 67.0 & 95.6 & A \\
\hline
\end{tabular}
A incouplete recovery obtained
B animal ated 
Table $v$ isfeets of substituted eyclohexylamine hydrochloride derivatives on the blood pressure of cats

\begin{tabular}{|c|c|c|c|}
\hline 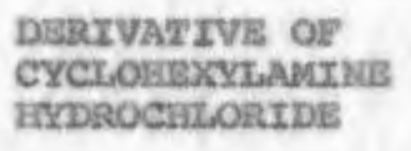 & $\begin{array}{l}\text { Dosis } \\
(\mathrm{mg} / \mathrm{kg})\end{array}$ & $\begin{array}{l}\text { NORUQA. } \\
\text { BLOOD PRESSURE } \\
\text { (min) }\end{array}$ & $\begin{array}{l}\% \text { DERRESSTON } \\
\text { TN ETOOD } \\
\text { PRESSURE }\end{array}$ \\
\hline erans $-2-0-\operatorname{toly} \mathbf{1}$ & 6.0 & 122.5 & $53.5^{\prime}$ \\
\hline trans-2-o-to $2 y^{2}$ & 12.0 & 240.0 & 78.6 \\
\hline c1s-2-2-toly1 & 12.0 & 140.0 & 67.9 \\
\hline trans $-2-p-\operatorname{tol} y^{2}$ & 12.0 & 140.0 & A \\
\hline els-2-2-toly2. & 12.0 & 140.0 & 65.2 \\
\hline
\end{tabular}

$A$ animal died 1 minute after infection 
Iable VI A comparicon of the $\mathrm{BD}_{50}$ (hypotensive) of substituted cyclohexylamine hydrochloride derivatives tested on the blood pressure of rats

\section{CrCLOEAXTHAIIE BRDROCALORIDI} DaRTVARTV

$\tan -2-0-01 \mathrm{yl}$

cis $-2-0-$ tolyl

trans $-2-2-$ tolyl

ciss $-2-2-$ tolyl

\section{3}

10.3

9.0

9.0

a. onleuloted by the method of Iltchfield and wilcoron (1949) 
Fig. 3 A comparison of the hypotensive effects produced by substituted cyclohexylamine hydrochloride derivatives in rats.

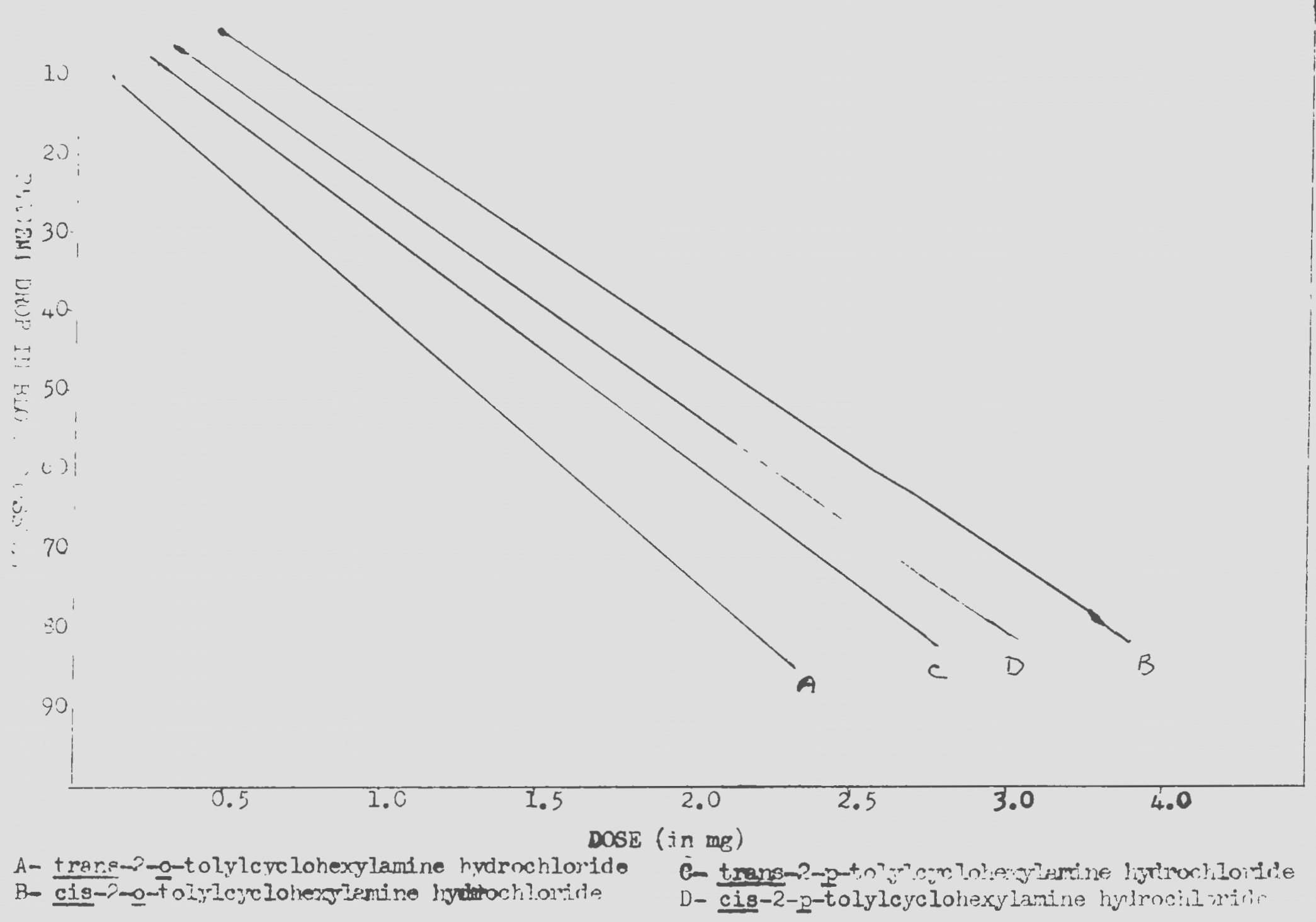


Table VII A comparison of the effects of substituted cyclohescylandine hydrochloride derivatives on tho blood pressure of rats and cats

\begin{tabular}{|c|c|c|c|}
\hline 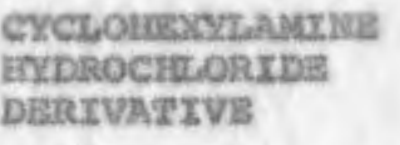 & $\begin{array}{l}\text { DOsE } \\
(\mathrm{mg} / \mathrm{kg})\end{array}$ & $\begin{array}{l}x \text { DEPRBS } \\
\text { ERODUCLD } \\
\text { IN RARS }\end{array}$ & $\begin{array}{l}\text { \% DSPRESSIOW } \\
\text { PRODUCRD } \\
\text { IN CARS }\end{array}$ \\
\hline trans & 6.0 & 48.9 & 53.5 \\
\hline trans-2-e-toly1 & 12.0 & 76.7 & 78.6 \\
\hline als-2-o-tolyl. & 12.0 & 53.6 & 67.9 \\
\hline trens $-2-2-t o l y 1$ & 12.0 & 52.0 & $\mathbf{A}$ \\
\hline cis-2-2-toly1 & 2.2 .0 & 52.2 & 65.2 \\
\hline
\end{tabular}

A animai dise during injection of this ase 
2. Sffects of Substituted Gyolohexylabine Fydrochleride Pro=

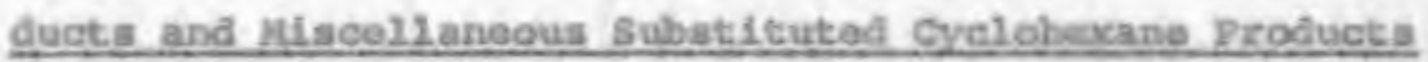
on the Isolated Guinea Dig Heart

a. Experimental Proceduras

Guibea piga of both sexses voighing between 0.442 and $1.000 \mathrm{Kg}$ ware aeeriffeed by oervical dialocation. The $x$ this were cut, the thoracie cavity was opened and the aorta was mobilized. A glase canrula was then accured to the aorta and a Low ind114liters of varm perfusate was injected into the cannula to ramove all residual blood in the cortanary vessela. The heart was then retaoved froa the andwal. All surrounding thasue vas ramoved and the heart vas placed into the poxfuaion chanber.

The porfusion chunber vas of the Anderaon-Craver type. " the vater in the outur jacket vas wadntained at $37.5^{\circ} \mathrm{C}$ by a recyeding pump whieh contained a heating unit. The perfusion suld wes lntrodusod at a conmtant rate malntalnod by air preasure to the driner coil lobding to the cannala containing the heart. The porfusion fluid was rocyoled, encept after the injection of a drug wan at least $30 \mathrm{ml}$. was withdrawn to insure reaoval of the drug. The tanperature of the pexfusion chaubar vas alvaya anintained at $37.5^{\circ} \mathrm{c}$.

After the preparation had atabilised, a hook was passed through the apex of the heart. A thread

a. Metro Indasterles, Loag Island City, M. Y. 
eocinected the hook vila a pullay systen to a myograph, where recordings woxe made on a physiograph,"

The porfusion fluid used for wl1 the experimats was that recomanded by Chenoweth and Koelle (1946) with one modiflaation. Atagnesium chloride was replaced with an eguivalent amount of magnoaium mulfate, in order to reduce the chloride ion content which will facilitate contractions.

A ttock solution containing all of the ingrecients, except the desterose and solitue blearbonate was preperad, Tho latter two were added on the day that the required anountel of the perfusion solution vere pirepared. The pertuaton golution vas aorated tisfing 95 per cent oxygon and 5 por cont earbon disoxide.

Injections of the drug wore sade into a opecial outlet from the porfusion chanber. Jach injection was imatiately followad with an injection of $1.5 \mathrm{ml}$. (the esleutated voluns of the apectal injection apiral) of perfusate to insure conplete adminiatration of the drog.

The drugs witeh were disadved in the polyethylaneglyeal 400 were all adninistered in $0.25 \mathrm{~b}$. of that solvent. Control dosea of $0.25 \mathrm{ml}$. of polyathyleneglyeol 400 vere adainigterod and the effects wore xogocded.

Each preparation vas testod frou oto to five timas Gopending on the recovery tron the provious doso, at leakt twenty ainutes vas alzowsd between infectionin to allow the proparation to atabilize sufeielently.

B. $\mathrm{E}$ a $\mathrm{X}$ Instrunant Co. Ilovatom, Fooce: 
Drug activity was aeasured by the following paxasaters: 1. The change in the amplitude of contraction.

2. The change in the rate of the heart.

3. The time to return to 50 per cent of the normal contraction.

b. Results

The results include the followings

1. Tho affects of substituted cycloherylaeine hydrochlorida derivativas on the isolated guinea pig heart. (Febles vIII to $\mathrm{xI}$ )

2. The effects of alnoollanocus substituted cyclohoxano derivatives and the polyethyleneglycol 400 control dose. (Tables XII to XVII)

3. The conparative affeets of the aubstituted cyclohesylamine bycirochloride derivatives on the isolated guinoa pig heart. (Table xVIII)

4. The conparative effects of the aiscellaneous substituted oyelohexane derivatives on the isolated guinea pig heart. (Table XIX) 
Table VIII Bffects of trass-2-p-tolylcyelohesceylamine hydrochloride on the isolated guinea pig heart

\begin{tabular}{|c|c|c|c|c|c|}
\hline $\begin{array}{l}\text { Doses } \\
\text { (mg.) }\end{array}$ & 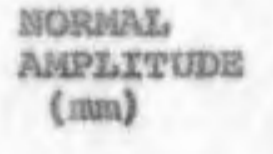 & $\begin{array}{l}\text { AMPLIZTUDE } \\
\text { \% CHALEB }\end{array}$ & $\begin{array}{l}\text { MORNALL } \\
\text { RATE } \\
\text { (per minute) }\end{array}$ & $\begin{array}{l}\text { RATE } \\
\text { \% CHANGS }\end{array}$ & $\begin{array}{l}\text { 2xus or } \\
50 \% \text { reTruR } \\
\text { (minutea) }\end{array}$ \\
\hline 0.19 & 24.0 & -57.2 & 13.6 .0 & +6.9 & 2,0 \\
\hline 0.38 & 28.0 & -96.4 & 124.0 & +6.9 & A \\
\hline 0.57 & 11.0 & -59.1 & 114.0 & F & 6.5 \\
\hline 0.95 & 13.0 & -76.9 & 108.0 & F & 21.0 \\
\hline
\end{tabular}

A. recovery incouplete

7. Itbrillation occuxred 
Table IX Effects of eis-2-p-tolyleyclohescylamine hydrochloride on the isolated guinea pig heart

\begin{tabular}{|c|c|c|c|c|c|}
\hline $\begin{array}{l}\text { Dose } \\
\text { (neg.) }\end{array}$ & $\begin{array}{l}\text { NORBAL, } \\
\text { MGSPLITUDE } \\
\text { (mai) }\end{array}$ & $\begin{array}{l}\text { AMPLTYUDE } \\
\text { \% CIIALGE }\end{array}$ & $\begin{array}{l}\text { NOEMAL } \\
\text { RATZ } \\
\text { (pox minute) }\end{array}$ & $\begin{array}{l}\text { RAFE } \\
\% \text { CFANGE }\end{array}$ & $\begin{array}{l}\text { TTLS OF } \\
50 \% \text { RETuR } \\
\text { (minutes) }\end{array}$ \\
\hline 0.40 & 24.0 & -75.0 & 242.0 & $F$ & $\mathrm{~A}$ \\
\hline 1. 20 & 25.5 & -100.0 & 128.0 & -100.0 & A \\
\hline 2.40 & 30.0 & -100.0 & 132.0 & -100.0 & 4.25 \\
\hline
\end{tabular}

A. xecovery inconplete

F. fibrillation oceurred 
Table $x$ Bffects of trans-2-o-tolyleyclohexylamine hydrochloride on the isolated guinea pig heart

\begin{tabular}{|c|c|c|c|c|c|}
\hline $\begin{array}{l}\text { Doss } \\
\text { (mg.) }\end{array}$ & $\begin{array}{l}\text { WORLAL } \\
\text { AMPLITUDB } \\
\text { (ma) }\end{array}$ & $\begin{array}{l}\text { AMPLITPUDE } \\
\text { \% CHANGE }\end{array}$ & $\begin{array}{l}\text { NORMar, } \\
\text { RATE } \\
\text { (per alnute) }\end{array}$ & $\begin{array}{l}\text { RAFE } \\
\text { \% CHANGE }\end{array}$ & $\begin{array}{l}\text { TIME OR } \\
50 \% \text { RBTUR } \\
\text { (minutes) }\end{array}$ \\
\hline 0.38 & 27.5 & -94.5 & 90.0 & -2.2 & A \\
\hline 0.38 & 34.0 & -92.6 & 96.0 & +4.2 & A \\
\hline 0.95 & 30.0 & -50.0 & 148.0 & -10.8 & $A$ \\
\hline 1.90 & 33.5 & -94.0 & 108.0 & -7.4 & A \\
\hline 3.80 & 29.5 & -100.0 & 80.0 & -100.0 & A \\
\hline
\end{tabular}

A. recovery inccuplete 
Table $x z$ Iffects of cis -2-0-tolyl cyclohexylanine hydroehloride on the isolated guinea pi.g heart.

\begin{tabular}{|c|c|c|c|c|c|}
\hline $\begin{array}{l}\text { DOSE } \\
\text { (mg.) }\end{array}$ & $\begin{array}{l}\text { NORUALI, } \\
\text { AMPLITUDE } \\
\text { (wa) }\end{array}$ & $\begin{array}{l}\text { AMPLITUDE } \\
\text { \% CHANGS }\end{array}$ & $\begin{array}{l}\text { NORWAL } \\
\text { RATE } \\
\text { (per minute) }\end{array}$ & $\begin{array}{l}\text { RATE } \\
\% \text { CHANGB }\end{array}$ & $\begin{array}{l}\text { zINE OF } \\
50 \% \text { RBgura } \\
\text { (minutes) }\end{array}$ \\
\hline 0.63 & 51.0 & -72.5 & 99.0 & -11.1 & 2.67 \\
\hline 1.26 & 20.0 & $-35.0 \mathrm{~B}$ & 108.0 & -8.3 & A \\
\hline 2.52 & 40.0 & +1.00 .0 & 152.0 & +36.8 & A \\
\hline 2.52 & 24.0 & -97.9 & 104.0 & -30.8 & 4.25 \\
\hline
\end{tabular}

A. recovery incomplete

B. stivalation followed the depression 
Table XII Eiffects of polvethyleneglycol 400 on the

isolated quinea pis heart

\begin{tabular}{|c|c|c|c|c|c|}
\hline $\begin{array}{l}\text { poss } \\
\text { (mil.) }\end{array}$ & 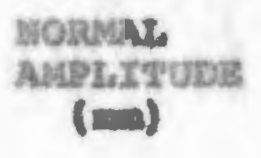 & $\begin{array}{l}\text { Adpritrude } \\
\% \text { cLakigB }\end{array}$ & $\begin{array}{l}\text { Norwall } \\
\text { Raws } \\
\text { (pos minute) }\end{array}$ & $\begin{array}{l}\text { RATB } \\
\text { \% CHANGE }\end{array}$ & $\begin{array}{l}\text { TtMU OF } \\
50 \% \text { Rares: } \\
\text { (minutea) }\end{array}$ \\
\hline 0.25 & 28.0 & -60.7 & 102.0 & -2.0 & 3.16 \\
\hline 0.25 & 32.0 & -59.4 & 96.0 & +20.8 & 2.40 \\
\hline 0.25 & 28.0 & -53.6 & 128.0 & -1.5 .6 & 3.0 \\
\hline 0.25 & 23.0 & -43.5 & 104.0 & -7.7 & $\mathrm{a}$ \\
\hline
\end{tabular}

A. recovery incomplete 
Table XIII Affects of 2-p-aethylphenylcyclohexanone (触202) on the isolated guinea pig heart

\begin{tabular}{|c|c|c|c|c|c|}
\hline $\begin{array}{l}\text { Dosg } \\
\text { (ng.) }\end{array}$ & $\begin{array}{l}\text { BORUYAL } \\
\text { MIPLITUDS } \\
\text { (ma) }\end{array}$ & $\begin{array}{l}\text { AMPLITUDS } \\
* \text { CHANGS }\end{array}$ & $\begin{array}{l}\text { NORWLI. } \\
\text { RATE } \\
\text { (per minute) }\end{array}$ & $\begin{array}{l}\text { RAIYE } \\
\% \text { CHANGB }\end{array}$ & $\begin{array}{l}\text { 5.wB OF } \\
50 \% \text { RJTuRu } \\
\text { (minutes) }\end{array}$ \\
\hline 3.24 & 9.3 & -67.7 & 102.0 & -4.9 & 2.75 \\
\hline 4.32 & 10.0 & -25.0 & 66.0 & +9.2 & 4.67 \\
\hline 4.32 & 49.0 & -87.8 & 129.0 & -25.6 & 3.50 \\
\hline 5.40 & 36.0 & -100.0 & 127.0 & -100.0 & A \\
\hline 5.40 & 24.0 & -1.00 .0 & 212.0 & -2.00 .0 & 7.33 \\
\hline
\end{tabular}

A. recovery incomplete 
Table XIV Elfoot: of 2-o-inethylphenylcyclohexanone (th203) on the isolated guinea pig heart

\begin{tabular}{|c|c|c|c|c|c|}
\hline $\begin{array}{l}\text { Dosis } \\
\text { (ag.) }\end{array}$ & $\begin{array}{l}\text { NOPaval, } \\
\text { NopuITUDE } \\
\text { (mil) }\end{array}$ & $\begin{array}{l}\text { AMPLITUDE } \\
\text { \% CHANTOB }\end{array}$ & $\begin{array}{l}\text { NORUAL } \\
\text { RATS } \\
\text { (per minute) }\end{array}$ & $\begin{array}{l}\text { RATE } \\
\% \text { CHANIEE }\end{array}$ & $\begin{array}{l}\text { TIME OF } \\
50 \% \text { RBMURA } \\
\text { (minutes) }\end{array}$ \\
\hline 2.06 & 27.0 & -64.7 & 126.0 & -7.9 & 1.5 \\
\hline 4.12 & 21.0 & -100.0 & 75.0 & $-100 \cdot 0$ & A \\
\hline 0.17 & 25.5 & -100.0 & 116.0 & -100.0 & A \\
\hline 0.22 & 17.5 & F & 114.0 & $\mathbf{P}$ & A \\
\hline 10.27 & 11.0 & -100.0 & 102.0 & -100.0 & $\mathbf{A}$ \\
\hline
\end{tabular}

A. recovery incoraplete

F. Eibrillation oceurred 
rable xv Effects of 2-o- tolylcyclohexen-2-one (泮204) on the isolated guinea pig heart

\begin{tabular}{|c|c|c|c|c|c|}
\hline $\begin{array}{l}\text { Dose } \\
\text { (mag.) }\end{array}$ & $\begin{array}{l}\text { NORNAL } \\
\text { AMPLITUDB } \\
\text { (man) }\end{array}$ & $\begin{array}{l}\text { AMPLITUD: } \\
\text { \% CEANUER }\end{array}$ & $\begin{array}{l}\text { NORMAL } \\
\text { RATE } \\
\text { (per minate) }\end{array}$ & $\begin{array}{l}\text { RATE } \\
\% \text { CHANGE }\end{array}$ & $\begin{array}{l}\text { THME OF } \\
50 \% \text { rRWuR } \\
\text { (minutes) }\end{array}$ \\
\hline 0.75 & 19.0 & -47.4 & 102.0 & +2.0 & $\mathbf{A}$ \\
\hline 2.12 & 24.5 & -57.2 & 105.0 & -4.8 & 1.67 \\
\hline 1.50 & 31.0 & -48.3 & 114.0 & -5.3 & $A$ \\
\hline 1.87 & 21.0 & -85.7 & 112.0 & -5.4 & A \\
\hline
\end{tabular}

A. recovery incoiplete 
Table XVI Effect: of 2-q-tolyleyelohest-4-en-Lol (\$205) on the isolated guinea pig heart

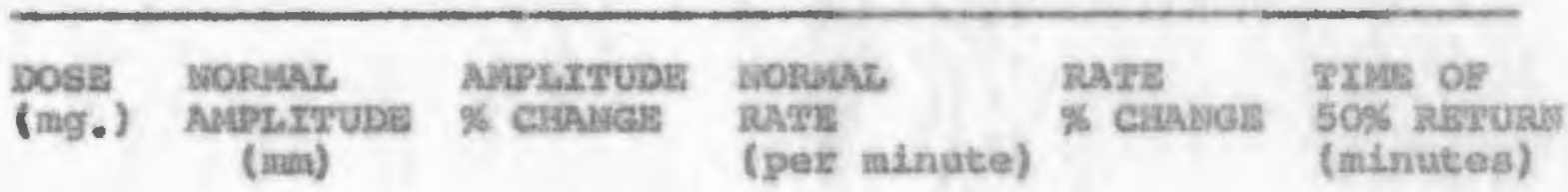

\begin{tabular}{llllll}
\hline 1.95 & 25.0 & -36.0 & 105.0 & -4.8 & A \\
2.875 & 25.0 & -40.0 & 108.0 & -19.8 & A \\
3.90 & 33.0 & -57.9 & 84.0 & -3.0 & 2.33 \\
3.90 & 38.0 & -93.9 & 65.0 & -4.8 & 4.40 \\
4.825 & 13.5 & -55.6 & 90.0 & -26.7 & 4.75 \\
\hline
\end{tabular}

A. recovery incouplete 
Fable XVII Bffeets of ethyl-2t-tolyl-1-hydroxy') cyclohexylacetate (a206) on the ialated guinea pig heart

\begin{tabular}{|c|c|c|c|c|c|}
\hline me & MORUAL & AwPLITupe & Moreral. & RATE & TrIuE OP \\
\hline & $\begin{array}{l}\text { ANPLITUDS } \\
\text { (an) }\end{array}$ & \% CHANGE & $\begin{array}{l}\text { BAIRE } \\
\text { (per adinutee) }\end{array}$ & \% CHANGE & $\begin{array}{l}50 \% \text { RETUIT) } \\
\text { (ninutes) }\end{array}$ \\
\hline
\end{tabular}

\begin{tabular}{llllcc}
\hline 1.52 & 29.0 & -37.9 & 208.0 & 47.4 & $\mathrm{~A}$ \\
2.52 & 39.0 & -51.3 & 118.0 & +1.7 & $\mathrm{~A}$ \\
2.20 & 13.0 & -96.2 & 114.0 & +12.3 & $\mathrm{~A}$ \\
3.04 & 44.0 & -56.8 & 124.0 & 0.0 & 0.75 \\
3.80 & 36.5 & -63.0 & 123.0 & -2.4 & $\mathrm{~A}$ \\
\hline
\end{tabular}

A. recovery incoiaplete 
TABLIE XVIII The comparative effects of substituted cyclohoxylamine hydrochloride derivatives on the isolated guinea pig hoart

\begin{tabular}{|c|c|}
\hline CYCLOHEXYLAMINE DERTVATIVE & $\begin{array}{l}\text { MINIMUMA DOSE USED WHICH PRO- } \\
\text { DUCED } 100 \% \text { DISPRESSION OF HEARI } \\
\text { (CArdiae Arrreat) } \\
\text { (ag.) }\end{array}$ \\
\hline $\operatorname{tran} 2-2-2-\operatorname{tol} y 2$ & A \\
\hline$a 11-2-p-t o l y 1$ & 1. 20 \\
\hline trans-2-o-tolyl & 3.80 \\
\hline cis $-2-2-t o l y^{2}$ & A \\
\hline
\end{tabular}

A. Compound did not produce $100 \%$ depression of the lreart. 
rable XIX Conprative offects of the aiscellaneous subatituted cyclohexane dorivatives on the isolated guinea pig hart

Comound

MINIMUN DOSE USED WHICH PRODUCED

SO\% DEPRESSION ar THE HEART (ag.)

2-p-tolylcyclohexanone (\$202)

3.14

2-o-tolyleyclobaxanone (*203)

2.06

2-o-tolyloyclohexen-2-one (\#204)

1.12

2-ㅇ-tolyl cyclohex-4-en-1-ol. (\$205)

3.90

ethyl-2-(2-tolyl-1-hydroxy) cyclohexyl-

1.52 acetate (\$206) 


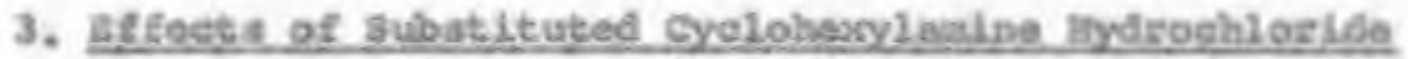

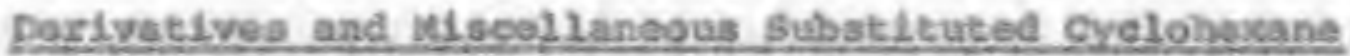
Derivativas on the Isolated gat Atria

a. Esparimental proeedures

Albino rats wore saceificed with a sharp blow to the

have. The thoracie eavity was axposed and the hoert was

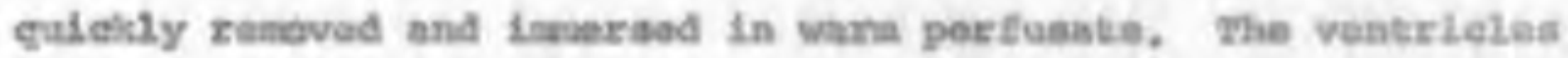
waro gontly oonpresead to ramove blood romaining in the chembers. The atria wore separated tron the vontricles and exttranoous tinabe was renoved.

The atrin vere placed in a $70 \mathrm{ml}$. tiasso beth (Magnus) maintainod at $32^{\circ} \mathrm{c}$, A hook from the aeration tube anchored the tigave at one and. Tho other end of the tussue vas attaehed to s hook which was eonnected via throad to a ayograpis, Recordinge vere made on a Mhyaiograph, a

The perfusion solution exployed vas the sase st thet whod for the Loolated puinoa pig hescts. Afr was gently bubled through the parfuadon solution in the tiasub bath. Who preparation was allowed to atablilso for at least E1fteen minutes before the firat taat was mado. when and if the tisten resovared adeguately, one te four teats wara conducted on ench tiseue prephration, Drugse vere sdiminietered from a ayringe Airectly into the tinsue chanber. ALI dosea of the drug Afasolved in polyetryleneglyeol 400 eonteasned $0.25 \mathrm{~m}$. of thet solvent. Cantrol studias, uaing $0.25 \mathrm{al}$. of

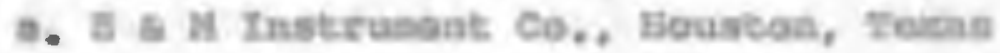


polyothyleneglyool 400 alone ware carríd out.

Three minutea after the injeotion vas made, the per-

frasion fluid was removed. Followlng two washings, frebh warn perfuaion 2luid was then adiled to the tissue chamiver. Tha changes produced by the flrug usuelly persiated through eha entire three minute teat geriod until washing. Several studiea allowing a five winute perlod of drug action prior to vashing wore also made. Only one dose was teoted in each preparation of the five ainute studies.

b. Resultes

The results include the following:

(1) Beflects of substituted cyclohexylanine hyaxochloride derivatives on the foolated rat atria. (rable $x 0 x$ to $x 0 x x x$, 2ig. 4)

(2) Effeets of miscellaneous substituted cyelohexane derivatives on the isolated rat atria. Fable XXrV to XCrtx, 7ig. 5)

(3) The oumparative effects of substituted cyclohesclanibe byârochloride derivatives on the isolated rat atria. (Table xck) 
Fable $x$ Bffect of trans-2-2-tolyleyclohexylamine hydrochioride on the leoleted rat atria

\begin{tabular}{|c|c|c|}
\hline $\begin{array}{l}\text { pos: } \\
\text { (-wg.) }\end{array}$ & $\begin{array}{l}\text { AMPLTTUDE } \\
\times \text { CHNaP }\end{array}$ & $\begin{array}{l}\text { RAMB } \\
\% \text { CHANGB }\end{array}$ \\
\hline 1.9 & +45.0 & -26.7 \\
\hline 1.9 & 0.0 & 0.0 \\
\hline 3.8 & +83.8 & 0.0 \\
\hline 3.8 & +57.7 & -7.9 \\
\hline 5.7 & +50.0 & -50.7 \\
\hline
\end{tabular}


rable xxI cffect: of cis-2-2-tolyleycloherylantne hydrom chloride on the 1solated zat atria

\begin{tabular}{|c|c|c|}
\hline $\begin{array}{l}\text { DOEB } \\
\text { (mg.) }\end{array}$ & $\begin{array}{l}\text { Mxpritud: } \\
\text { x chanes }\end{array}$ & $\begin{array}{l}\text { RA2I } \\
\% \text { CFANGE }\end{array}$ \\
\hline 1.2 & +77.8 & -25.0 \\
\hline 2.4 & +7.4 & -26.9 \\
\hline 4.8 & -42.9 & -21.9 \\
\hline 4.8 & -30.4 & $-36 \cdot B$ \\
\hline
\end{tabular}


rable xxI Iffects of trans-2-0-toly lcycloheacylanine hydrochloxide on the isolated rat atria

\begin{tabular}{|c|c|c|}
\hline $\begin{array}{l}\text { pose } \\
\text { (ang.) }\end{array}$ & $\begin{array}{l}\text { AMrLITUDE } \\
\% \text { CEANGE }\end{array}$ & $\begin{array}{l}\text { RATE } \\
\% \text { CFANCE }\end{array}$ \\
\hline 0.19 & +11.1 & -20.0 \\
\hline 3.8 & 450.0 & $-61 \cdot 2$ \\
\hline 7.6 & +45.0 & -53.5 \\
\hline
\end{tabular}


rable xxIII iffect: of efs-2-0-tolyleyclohescy lamine hydrochloride on the 1solated rat atria

\begin{tabular}{|c|c|c|}
\hline $\begin{array}{l}\text { pose } \\
\text { (agg.) }\end{array}$ & $\begin{array}{l}\text { Aast.IwUDS } \\
\text { \% cEAvis }\end{array}$ & $\begin{array}{l}\text { RaTRE } \\
\text { \% CIAAUGE }\end{array}$ \\
\hline 0.63 & +37.5 & -27.2 \\
\hline 0.63 & +54.9 & -14.9 \\
\hline 0.63 & +102.9 & -22.5 \\
\hline 1.26 & +58.3 & -46.3 \\
\hline 1.26 & +33.3 & -27.5 \\
\hline 1.25 & -3.2 & -4.6 \\
\hline 1.26 & +3.3 & -2.7 \\
\hline 2.52 & +177.8 & -45.5 \\
\hline
\end{tabular}




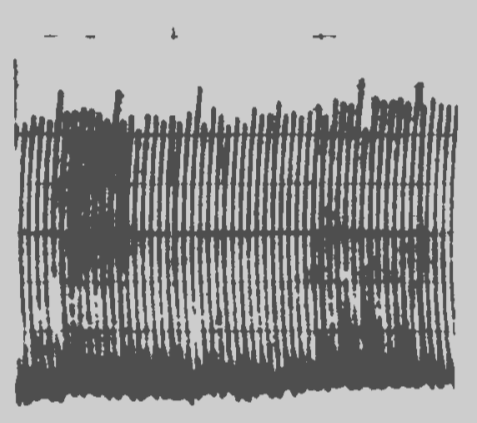

0
15

\section{$1: 13 \mathrm{ng}$}

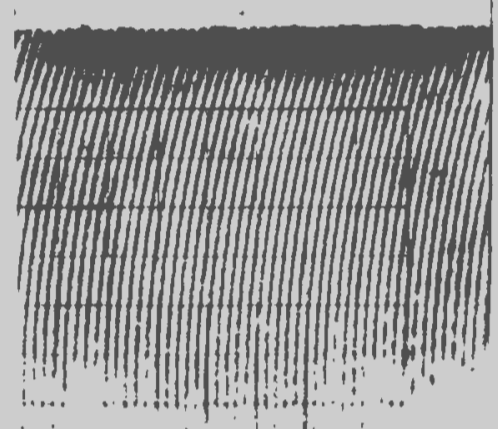

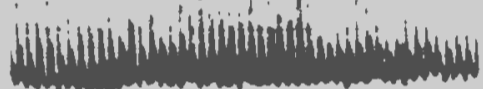

165

\section{TIME IN SECONLS}

Fig. 4 THE EFFECT OF 2-o-TOLYLCYCLOHEXEN-2-one (\#204) (1.13 mg) ON ISOLATED RAT ATRIA.

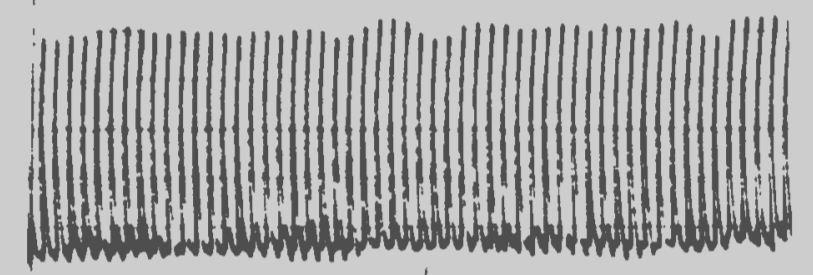

0

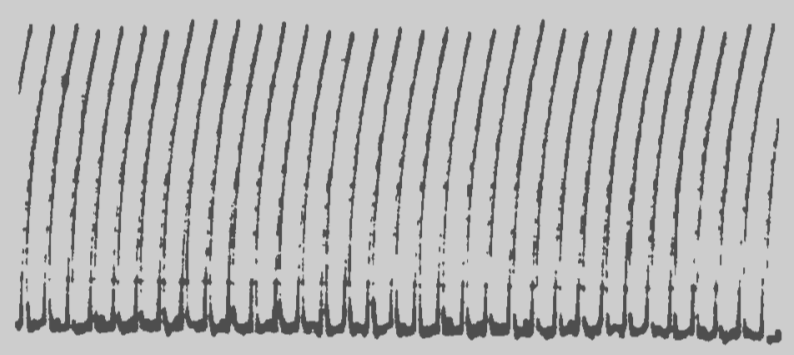

1.5
$3.8 \mathrm{mg}$

TIME IN SBCONDS

Fig. 5 THE EFFECT OF ETHYL-2-p-TOLYL-1-HYDROXYCYCLOHEXYLACETATE (\#206) $(3.8 \mathrm{mg})$ ON ISOLATED RAT ATRIA. 
Table XXIV Bffects of polyothyleneglyeol 400 on the isolated rat atria

\begin{tabular}{|c|c|c|}
\hline $\begin{array}{l}\text { DOSE } \\
\text { (m1.) }\end{array}$ & $\begin{array}{l}\text { ANPLXTTUDS } \\
\% \text { chawes }\end{array}$ & $\begin{array}{l}\text { RATES } \\
\text { \% CBAMESS }\end{array}$ \\
\hline 0.25 & +15.6 & -1.9 \\
\hline 0.25 & +23.3 & -52.5 \\
\hline 0.25 & +17.8 & $-5,6$ \\
\hline 0.25 & +16.4 & +7.7 \\
\hline
\end{tabular}


Table XxV Effects of 2-p-methylphenyl oyclohexanone (A202) on the isolated rat atria

\begin{tabular}{|c|c|c|}
\hline $\begin{array}{l}\text { poss } \\
\text { (rag.) }\end{array}$ & $\begin{array}{l}\text { AMPLITUDB } \\
\text { \% CraAIGB }\end{array}$ & $\begin{array}{l}\text { RAIE } \\
\text { \% CIANEGE }\end{array}$ \\
\hline 3.14 & +3.7 & -8.3 \\
\hline 4.32 & +10.9 & 0.0 \\
\hline 4.32 & +25.0 & +47.21 \\
\hline 4.32 & +4.8 & -20.6 \\
\hline 5.4 & $\uparrow 25.0$ & $+5.8 *$ \\
\hline
\end{tabular}

* increase 
Table XxvI Iffects of 2-0-methylphenyleyclohexanone (4203) on the isolated rat atria

\begin{tabular}{|c|c|c|}
\hline $\begin{array}{l}\text { Dosis } \\
\text { (nis.) }\end{array}$ & $\begin{array}{l}\text { AMELITUDE: } \\
\text { \% cBALGas }\end{array}$ & $\begin{array}{l}\text { RATS } \\
\% \text { CEAMGS }\end{array}$ \\
\hline 4.21 & +23.3 & -16.0 \\
\hline 6.17 & +24.1 & -9.5 \\
\hline 8.22 & -23.1 & -33.3 \\
\hline 10.27 & 0.0 & -42.9 \\
\hline
\end{tabular}




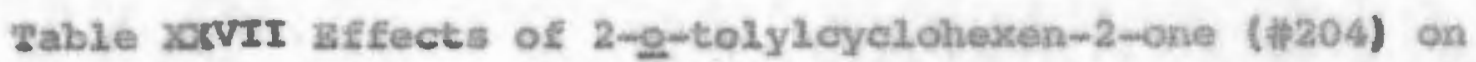
the isolated rat atria

\begin{tabular}{|c|c|c|}
\hline $\begin{array}{l}\text { DOSE } \\
\text { (mg.) }\end{array}$ & $\begin{array}{l}\text { AMPLITUDS } \\
\text { \% CHANGB }\end{array}$ & $\begin{array}{l}\text { RARE } \\
\text { \% CHABCE }\end{array}$ \\
\hline 0.75 & +1.6 .3 & -5.9 \\
\hline 1.13 & 475.4 & -9.1 \\
\hline 1.30 & +30.8 & -8.3 \\
\hline 1.30 & $\div 29.2$ & -8.9 \\
\hline 1.50 & +170.5 & -24.3 \\
\hline
\end{tabular}




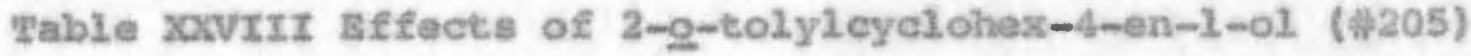
on the isolated rat atria

\begin{tabular}{|c|c|c|}
\hline $\begin{array}{l}\text { Doss } \\
\text { (mg.) }\end{array}$ & $\begin{array}{l}\text { AMPLIYUB: } \\
\text { \% CHALG: }\end{array}$ & $\begin{array}{l}\text { RATE } \\
\% \text { CHA2GE }\end{array}$ \\
\hline 1.95 & +42.9 & $-18 \cdot 2$ \\
\hline 2.89 & 422.4 & -2.2 \\
\hline 3.9 & +5.3 & -17.2 \\
\hline 4.83 & +6.4 & -14.2 \\
\hline
\end{tabular}


Table XXIX Bffects of ethyl-2tp-tolyl-1-hydroxyl cyclohexylacetate (\$206) on the isolated rat atria

\begin{tabular}{|c|c|c|}
\hline $\begin{array}{l}\text { Dose } \\
\text { (mg.) }\end{array}$ & $\begin{array}{l}\text { AMPLITUD: } \\
\text { \% cHANGS }\end{array}$ & $\begin{array}{l}\text { RAVE } \\
\text { \%6 CFABNCS }\end{array}$ \\
\hline 1.52 & +4.3 & -11.0 \\
\hline 2.28 & 429.2 & -25.0 \\
\hline 3,04 & +42.9 & -29.4 \\
\hline 3.80 & +43.4 & -30.6 \\
\hline 3.90 & +43.2 & -37.0 \\
\hline
\end{tabular}


Table $x \times x$ A comparison of the five winute effects of substituted eycloherylamine hydrochloride derivatives on the rat atria

\begin{tabular}{|c|c|c|c|c|}
\hline 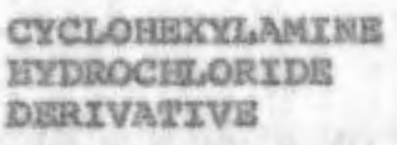 & $\frac{\text { DosE }}{\text { (nag.) }}$ & $\begin{array}{l}\text { TIMI BOR OSBST } \\
\text { OI ACYIOD } \\
\text { (seconds) }\end{array}$ & $\begin{array}{l}\text { AMpLxтuds } \\
\text { \% cindray }\end{array}$ & $\begin{array}{l}\text { 'RATE } \\
\text { \% CHAMGB }\end{array}$ \\
\hline trene-2-p-toly $y^{2}$ & 1.9 & 100 & +18.4 & 0.0 \\
\hline cis $-2-2-6 a l y 2$ & 1.9 & 180 & 0.0 & -43.1 \\
\hline trans-2-o-toly1 & 1.9 & 220 & 455.0 & -68.2 \\
\hline$c^{1} s^{-2}-0-t a l y 2$ & 1.9 & 120 & +34.6 & $-48 \cdot 2$ \\
\hline
\end{tabular}




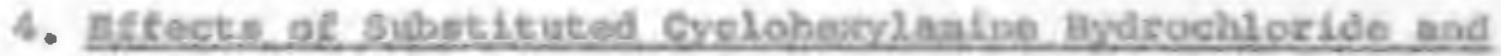
Mijoellanegus Cyclobegane Derivalivas on Isolated Guinea Pig Intestinal Strips

a. Bxperinental Drocelures

Guinea pigs were secrificed with a sharp blow to the base of the skuli. The abdoaun was quidkly opened and the inteatinal tinavea were exposed. The upger portion of the mall intestine, Including the duodesua, was renoved and ismediately placed in vara pexfusion solution whieth had aix

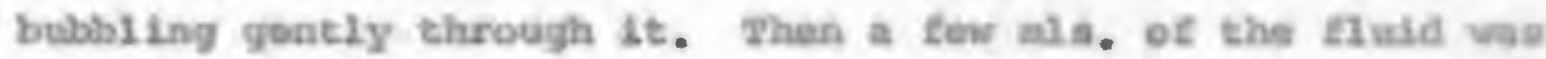
foread through the Itaan of the tiasue to rosove any pertieles preseant.

A $3 \mathrm{~cm}$. soction of the inteatine was then obtalned and placed fa a $75 \mathrm{ml}$ tastue bath (Alagava). The tanperature was ablntained ot $37.5^{\circ} \mathrm{c}$ throughout the experinent.

The perfusion solution esployed was the aause sa that used for the isolated guinea pig hoerts. Air was gontly bubled through the perfusing 21uid throughout the eipgerinent. The tiasue nection was enchored at the botton to a hook sonnected to tha bubling tube. The other and of the intestinsl etrip was hola by a hook and throad which lead to a myograph, kecondings were aale on a Phyidograph, a

Tho Lour eyelohexylanine bytrochloride salts and two of tha miscellanoous ayclohexene dorivatives vare tasted for theix action on isolated salil intestines. The malta vere watent solubler the other two ware dissolved in $1.00 \mathrm{ml}$. of

a. I and if Inntruaent Co. Bouston, Texas 
polyothylenoglyeol 400. Control experinonte were also run to detarnine the effects of $1.00 \mathrm{ml}$. polyothylenoglyool 400 alone. The drugs were infected direetly into the solution in the inner jacket.

The drugs were allowed to act for a three minute perLod. Following three successive washes, fresh solution was then added. If the tissue recovered eufficiently, it was used for up to three trials before belng repleced with a new otrip. The measures of drug ectivity include the following:

1. The change in the anplitude of contraction of the tissue.

2. The elhange in the rate of contraction of the intestinal atris.

3. The change In the tone of the tiesue strip.

4. The tim needed for the tone of the tlesue to return to noxwal.

b. Results

The results inalude the followings

(2) The tone did not roturn to normal in any of the experimente excopt once with 4.06 ag of ethyl-2-tp-tolyl-1hydraxy) oyclobaxylacetate (*206).

(2) The effects of substituted cyeloboxylandne hydrochloride derivatives on the isolated guinea pig mall intestines. (rables XoxI to Xoxivs rigs. 6 to 7 )

(3) The effects of polyothyleneqlycol 400 and miscellaneous substituted cyclobostane derivative on the isolated

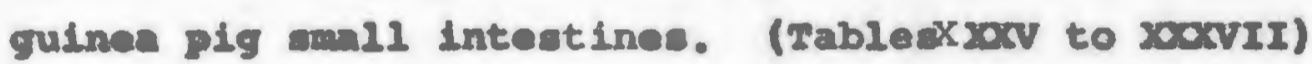


Table xoox Blfects of trans-2-p-tolyleyclohexylaiaine hydrochloride on the isolated grinea pig sinall intestine

\begin{tabular}{|c|c|c|c|}
\hline $\begin{array}{l}\text { coss } \\
\text { (mg.) }\end{array}$ & $\begin{array}{l}\text { AMPLITUDE } \\
\text { \& CHANCB }\end{array}$ & $\begin{array}{l}\text { RATE } \\
\% \text { CHANCS }\end{array}$ & $\begin{array}{l}\text { TOLEB } \\
\text { CHANGE } \\
\text { (min.) }\end{array}$ \\
\hline 0.205 & +358.3 & +5.9 & 0.0 \\
\hline 0.325 & +33.3 & +20.0 & 0.0 \\
\hline 0.524 & +25.0 & +60.0 & 0.0 \\
\hline 2.097 & +100.0 & +225.0 & -6.0 \\
\hline
\end{tabular}


Table wxxI Effects of ais-2-p-tolyleyclohexylamine hydrochloride on the isolated guinea pig small intestin

\begin{tabular}{|c|c|c|c|}
\hline $\begin{array}{l}\text { cosis } \\
\text { (mg, })\end{array}$ & $\begin{array}{l}\text { AUPLITUDB } \\
\text { * CaRNGS }\end{array}$ & $\begin{array}{l}\text { RATE } \\
\text { \% CLINGS }\end{array}$ & $\begin{array}{l}\text { TONE } \\
\text { CHANOE } \\
\text { (mm,) }\end{array}$ \\
\hline 0.24 & -100.0 & -100.0 & 0.0 \\
\hline 0.26 & -200.0 & -100.0 & $-10.0^{\mathrm{a}}$ \\
\hline 0.48 & -100.0 & -100.0 & -10.0 \\
\hline 0.48 & -100.0 & -100.0 & 0.0 \\
\hline 1.20 & -200.0 & -100.0 & -20.0 \\
\hline 2.10 & +25.0 & +11.1 & $-20,0^{b}$ \\
\hline
\end{tabular}

a. Daseline atimulated to $\$ 25.0$ ma.., then depressed. b. Baseline stimulated to $+39.0 \mathrm{mn}$. , then depressed. 
Table xocrir Bffects of trans-2-0-tolylcyclohessylamine hydroehloriâe on the isolated guinea pig small inteatine

\begin{tabular}{|c|c|c|c|}
\hline $\begin{array}{l}\text { Dosse } \\
(\operatorname{mgg} .)\end{array}$ & $\begin{array}{l}\text { ANupistrube } \\
\text { \% crames }\end{array}$ & $\begin{array}{l}\text { RATS } \\
\% \text { cHanes }\end{array}$ & $\begin{array}{l}\text { TONSE } \\
\text { CHANGE } \\
\text { (mun, ) }\end{array}$ \\
\hline 0.25 & +33.3 & -28.6 & 0.0 \\
\hline 0.50 & +27.3 & -44.4 & -5.0 \\
\hline 0.99 & 470.8 & 0.0 & -2.0 \\
\hline 0.99 & -50.0 & +500.0 & -5.0 \\
\hline 1.98 & +168.8 & +10.0 & -7.0 \\
\hline 1.98 & 430.6 & 48.3 & -15.0 \\
\hline
\end{tabular}


Table xoxIV grftects of cis-2-0-tolyleyclohexylanine hydrochloride on the isolated guinea pig amall inteatine

\begin{tabular}{|c|c|c|c|}
\hline $\begin{array}{l}\text { DOSE } \\
\text { (mg.) }\end{array}$ & 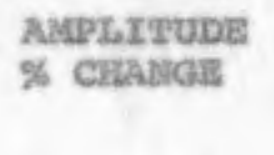 & $\begin{array}{l}\text { RHES } \\
\text { \% CIAAMGE }\end{array}$ & $\begin{array}{l}\text { Tonts } \\
\text { chanders } \\
\text { (ma.) }\end{array}$ \\
\hline 0.22 & +20.0 & -29.4 & 0.0 \\
\hline 0.56 & +24.0 & 0.0 & 0.0 \\
\hline 0.56 & +18.0 & +16.7 & 0.0 \\
\hline 1.11 & +6.0 & -35.0 & 0.0 \\
\hline 1.1 .1 & -55.0 & -84.6 & 0.0 \\
\hline 2.22 & +22.9 & +66.7 & -22.0 \\
\hline
\end{tabular}




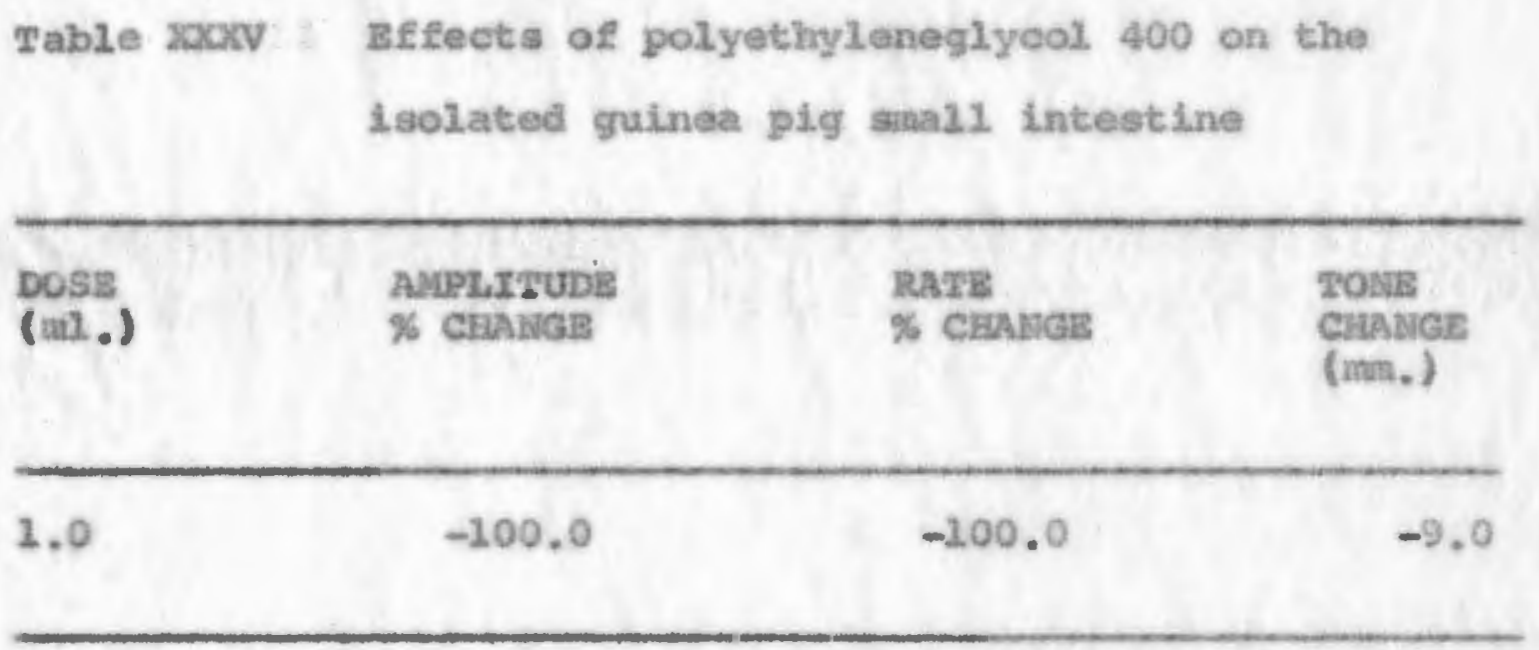


Table xxxvi Bffects of 2-12-iatchylpheayloyclohexanone

(t4202) on the isolated guinea pig small intestine

\begin{tabular}{|c|c|c|c|}
\hline $\begin{array}{l}\text { DOSE } \\
(\log .)\end{array}$ & 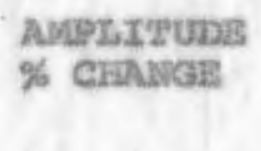 & $\begin{array}{l}\text { RANES } \\
\text { \% CHANas }\end{array}$ & $\begin{array}{l}\text { TONAS } \\
\text { CHAwar } \\
\text { (unt.) }\end{array}$ \\
\hline 1.1 .5 & -100.0 & -100.0 & -7.0 \\
\hline 2.16 & -78.8 & +76.2 & 0.0 \\
\hline 2.16 & -76.9 & -66.7 & -18.0 \\
\hline 4.62 & -100.0 & -100.0 & -8.0 \\
\hline
\end{tabular}


Table xoccuII Effects of ethyl-2-(2-tolyl-1-hydroxy) cyclohescylacotate (H206) on the isolated guinea pig small. inteotine

\begin{tabular}{|c|c|c|c|}
\hline $\begin{array}{l}\text { DOSB } \\
\text { (mg.) }\end{array}$ & $\begin{array}{l}\text { AMPLITUDE } \\
\text { \% CHIAISGE }\end{array}$ & $\begin{array}{l}\text { RATE } \\
\% \text { CHANGE }\end{array}$ & $\begin{array}{l}\text { TONE } \\
\text { CHANGE } \\
\text { (man.) }\end{array}$ \\
\hline 4.06 & +133.3 & +75.0 & $+33.0^{2}$ \\
\hline 4.06 & +27.3 & -12.5 & -36.0 \\
\hline 4.06 & 0.0 & +6.7 & +10.0 \\
\hline 8.13 & -67.2 & -3.4 & 0.0 \\
\hline 8.13 & +84.6 & -47.2 & -22.0 \\
\hline
\end{tabular}

a. Baseline returned to normal level after 2 minutes 5 seconds. 


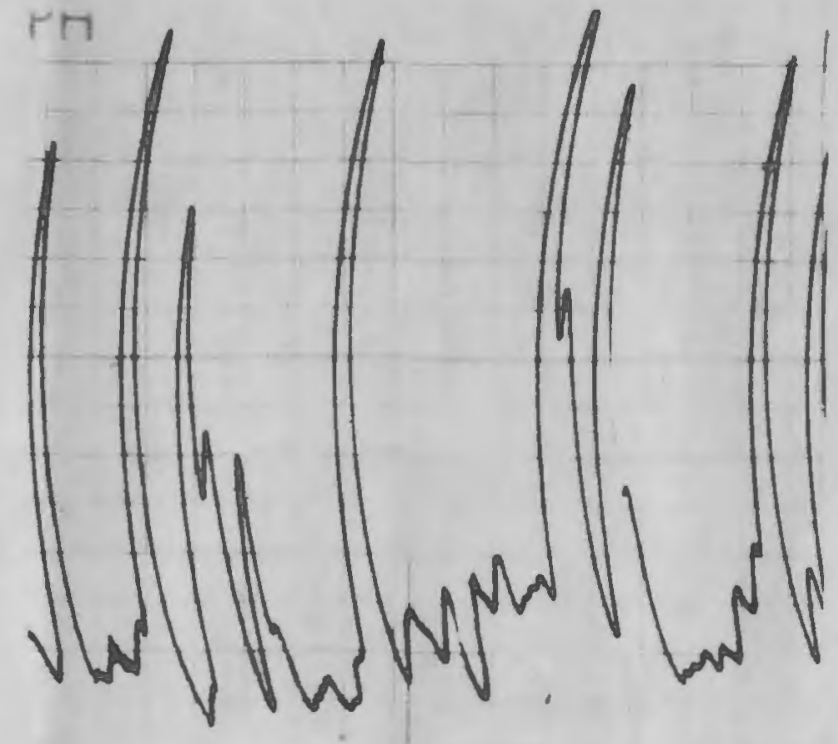

0
60

IHUECT

$1.98 \mathrm{mg}$

TIME IN SBCONDS

Fig. 6 THE EFFECT OF trans-2-o-TOLYLCYCLOHEXYLAMINE HYDROCHLORIDE (1.98 mg) ON ISOLATED GUINEA PIG INTESTINE.

0

$$
\begin{aligned}
& 60 \\
& \text { INWECT } \\
& 0.48 \mathrm{mg}
\end{aligned}
$$

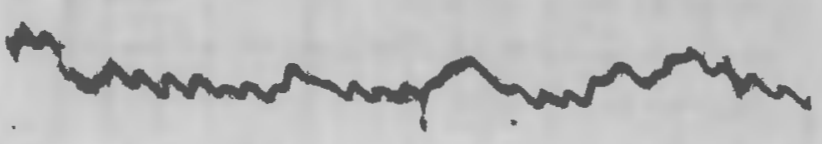

90 


\section{IV prscussrov}

Prelininary investigations by faitria at al. (1958) and Melaon at al. (295a) and a norte extansive inveatigation by Sacoicler and Debleo (1962) bave ahoim that 2-ary2 subatituted cyolohevanol cobpounds produde effects on the oardiovascular myatem. Cild and trang lachers of 2-2-toly1-, 2-2-chloropheny1and 2-2-ehlorophenyleyclobecanol wore teated Lor tholix sotions on isolated guinea pig hearts and found to deprese the heart: In varying degroes with sone produalng cardioplegia. It vos Found that the trang-2-g-toly abbeitution on the 2-ary position of the eyolohexanol molecule produced the greatest effects on the bliod preasure of lntaet rats and isolated

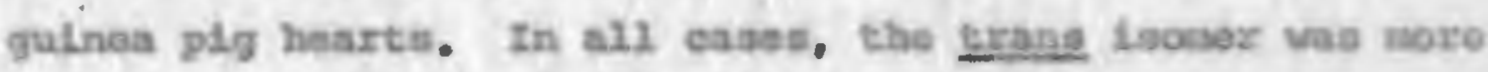
potent then its correirponding gife inomex. The tolyl derlvatives vere apparentiy lees tcocle than the chlorophenyl derivativea, as the latter ugually pravented the tisauss atudied Exas recovering thoir nortial levels.

A seriea of substituted cyclohexylanine hydrochlortale Cesivativas and othor miscellaneous cyclohescane derivatives ware syathoalzed by Muitric. The structure of these aospounda Is ahown on rables 1-2. They were teated for theix effeets on the blood pressure of intact cats and rate, on isolated guibea pig hearte. on faolated rat atria and on isoleted guinoa pig stall intestines.

The blood preasure studilea wore undortakan to sacertain their groes affects on the blood preasure. Only the eyclohexylanine hydxochloride derivatives vero studind in 
this portion of the exporiments as the others wore not water soluble. All the compounds studied produced an immediate drop In the blood prepeure wheh lasted for varying lengths of time. The amovint of depreselon produced seemed to vary with the dose of the canpund adminlotored. The trang-2-0-tolyl derivative of gyolohaylandne hydrochloride had the most potent effects on the bleod prescure of the rat. Cl1-2-0-tolylcyclohexylanine hydrochloride was the lenst potent of the series, and the ale and trane 1comers of 2-2 tolyl were about equal in their effects. similar effecte ware abeervod on the blood presauce of the cat. (Table VII)

It has been observed in these studies that whan increasing the dose above the lovel producing a 45 to $55 \%$ response, a lower degree of depression was obtained than previously obtained uning a lower dose. This can be seen in Table II where the responee to $18.0 \mathrm{mg}$. of the drug produced less depreasion than at 12.0 and $16.0 \mathrm{mg}$. Thls might indicate a corapensating mechandan coning into affect at this level of depression. In no case in the otudies on latact rats was the blood preasure redueed in an amount between 56.8 and $70.6 \%$. (Table I to Table IV) It 1s possble that a compensating mechanism is affecting the reaponse to these druge at thase dose levels.

Whon death occured duxing these blood proserure studies, 1t was often observed that the respiration ceased before the hourt stopped beating. Sometimes artifical respiration was able to prevent the death of the animal. despite the effects of the arwg.

All the coupounds wre tested for their actions on 
iadated guinea plg hearta. The presence of a Ainited quantity of the drugs prevented rare oxtensive teatlag of the conpounds in mone of these etudies. Iron rables VIII to XI. It can bo seen that the trang 1aomerg of tolyl eyclohexylamino hydroahloride were moxe potent thon the correspondiag eialieomers in thals ability to depress the auplitude of contractions. The effects on the rate of the heart: were mixed, some stimulating and sone producing depresaion. 2hn rate usual2y we not affected to a great aegree except in high doees whe the contractions vere alwoot totaliy depressed. It might appear that tho rate 10 Iftele affocted directly but ondy through the eflect on the auplitude of contractions. It searas thrt the I $\mathrm{h}$ node $1 \mathrm{~s}$ not the aite of action of thie sexies.

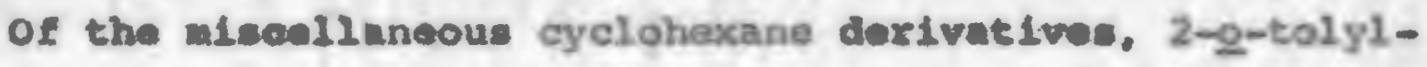
cyclahoxan-2-one (4204) we the most dapresaant, while 2-0-toly cyclohes-6-en-1-01 (\$205) was the least effective on the anplitude. N11 produced effects on the anplitude in varying degrees in excess of that produced by polyethyleneglyeol 400 along. (Table' XII) It is not known whether the deproseion produced by the polyechyleneglycol 400 and by the cyclohexane dexivatives is by the sama mechanisa or through a soparate action. The effects on the rate were varied, bous producing un increase and sona a decrease. When the ampl1tude was totally depreond, the rate al oo coased conpletely.

Studies on the rat atrla abowed thet the cyclohexylanine hydrodhloride derivatives increaced the amplitude of contractions while decreasing the rate. IInconsistencies occurred ampag the 2-toly1 derlvatives which produced apreasion rathex than a atimulation of the amplitude. In these atudies, It was shom 
that once again the trang-2-o-toly 1 derlvakive was most potent of this series and the dis-2-p-tolyl derivative lenet potent. The trane isomer was more potent than the corredponding of 1 isoner. The trans-2-g-tolyl derivative had no effect on the rate in inost. of the experiments. Ithe trrang-2-o-toly 2 corpound had the greatent effect on the rate. (Table X0xII)

The miacelianeous eyelohexane dexivatives al1 incresaed the amplitude of the atrin contrectiong and decreased the rate. The effects did not vary vith the dose and often a large dose had little effect. Thlo ary have been due to an actual depreasant - Ifect by the drag whlch overcam the otinulating effocts on the anditule of the polyethyleneglycol 400 ealvent. 2-o-tolylcyclobexcen-2-ane (1204) was the nowt potent (rable XXVII) and 2-0 tolylcyalohexanone (4203) and 2-p-tolylayclohexanone (4202) wore the leabe effoctiv. (Tables xav-XxVI)

In order to deteraine the effects on stoooth musdle, sone of the compound were then tooted on guinea pig sanil intestine. The Eovr aenbexa of the cyolohexylamine hydrochloride sex ies were tested, and all increased the axplitude excopt the gig-2-ptolyl derivative which greatly decreaned the anglitude of contractions to total depreasion. (Tsble xocxry) The effocts on the rate ware rariable and inconsistent. trrans-2-o-Tolylcyclohexylausine was the last potent, (Fable xXxIII), and the cis-2g-tolyl derivative was the least potent (Table XOCCrV). The cis-2-2-tolyl oompound was appaxenty toxle and totally depressed the tlavoe. The change in tone vas medsured in terma of the change in the baceline. The tzang-2-g-tolyl dorlvative degreseed the tone wh12e the cis-2-p-toly1 and the trans-2-g-toly 1 dex 1 raeimes ustanly did not alter the baseline. cis-2-p-Tolylcyolo- 
bexylanine bydrochoride depreseed the baseline. Ethyl-2te-toly1-1-hydroxy)eyclohexylacotate (W206) asual2y stimulated the anplitude and depressed the rate (rable xoxvII). 2-p-tolyloyclohescanone (-202) apparently had 1ittle effect on the rate or amplitude which was not due to the depreasant action of the polyethyleneglyeol 400 aolvent (Table xosvi).

From these experiments it appeaxs that tho cyclohexylanine bydipochoride derivatives affect the tisaue teated in anner sinilar to that of parasyapathetic stimulation. The actions - Llasted were a stimulation of intestinal contractiona and a depression of the anplitude of cardias eontractions and an overall hypotansive effect on the blood pressure. A fow otudies were nade in cats in which during the peak of the hypotensive action of the cyeloherklanine hydrochloride derivativea vagal atimulation was affected. Wo additional lowering of blood pressure zesulted froin this procedure. The carotid sinus relleses remained Intact duxing the Aepressant effects of the compounds. It $\mathrm{Lg}$ conceivable that these compounds may produca theis actions by involving mechanisms of the parasyapathetic nexvous systen. Furthor research in this direction might be feasible. 


\section{v. spogary}

The gite and trang-2-2-toly3 and tho ctis and trans-2-2toly2 derivatives of eyelohoxylanine hydrochloride and othor aiscollaneous gyeloheirane derivativas were teated for varlous pharanoologlcal actioas. The teata ineluded blood praeaure mtudies on intact rnts and eats, experisunts on Isolatod guinea pig hoarts, studiea using lableted rat atria and teste on lao-

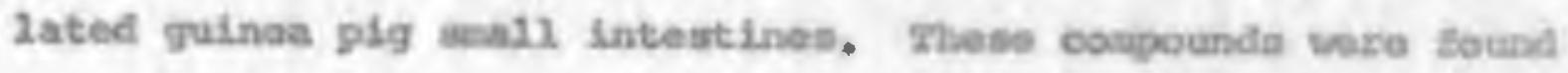
to activaly affoct the caxdiovaveular aystum and the anooth muscle tissvo toated.

Due to the linited vater solubility of the milacollaneous eyelobaxane compounds, ondy the four cyololvexylantine hydrodhloride Corivatives wore atrulied on integt rates and cato for theis gross blood pronure efteots. AIl prodnoed an ismediate Arop in blood prosaure, the hypotenalve eskect varying with the doee adninistered. 0 the eyelohurylamine nories testud, tha trana-2-2-tolyd derivative was the woot potent and pis-2-2toly2 was the least active. Noth the cleg and the trang-2-2toly2 derivativen producod ainilar hypotanuiva affects at ehe donagos tented. Thene sesultes vore obtasned in the blood presume studieo of both the rat and cat. Ho approciable differenees were obtained in the roaponases of the animals of thase two different: apecies to the compounds tested.

A11 the oompounds were tested for their actiona on Ioolated Juinoa plg hearts. of the oyelohesylanlne bydrochiorida series, the trane isoears vero wore potent than thoir

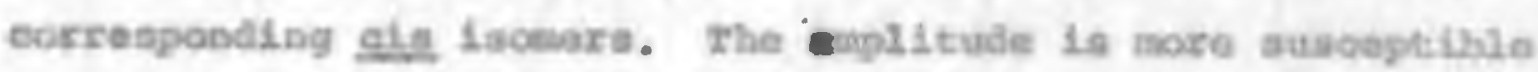


to the depressant action of these compounds than the rate. 2-o-tolylcyclohexen-2-one (i204) was the most potent of the aiccollaneous cyclohexane derivatives studied. 2-0-Tolylcyclohex4-en-1-ol (\#205) possensod the leset anount of activity on the isolated heart.

The trans-2-o-tolyl isomer of cyolohexylanine hydrochloride was the most potent of its series in affocting the rat atxla. The els $-2-2-t o l y 1$ derivative was the leat potent. 1. The ununl zesponse wes an increase in the amplitude of contractions.

Within the group of mireellaneous compounds tented, 2-o-tolylcyclohexen-2-one (1204) was the most potent in Ita action on the rat atria. 2-o-tolyl and 2-p-tolylcyclohescanone (\$202, \$203) were the least active on the rat atria. trans-2-0-501 ylcyclohexylamine hydrochloride produced the greatest amount of stimulacion to the small intentinal atrips. The cis-2-p-tolyl derivative was exceptional to the other members of this saries since it depressed the inteatine. Bthy1 -2-(2-toly1-1-hydroxy) cyclohexylacetate (米306) stimulated the small intextine while 2-p-tolylcyclohexanone (4202) had 2Lttle effect. 


\section{Conctustons}

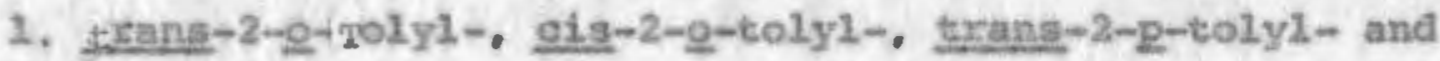
girs-2-2-tolyleyclohesylamine hydxochlortde are capalsle of dopressing myodeardial contractility and producing a kypotenaive effect. They stiaulate isolated atria and maj.1 intestine.

2. The tyang-2-e-tolyl position appeare to be the most active in this geries. The alg isoners were never nore active that the trans isomers in this series,

3. 2-2-201yleyelohescon-2-one ( the miacellaneous cyclohescone derivatives tested. 


\section{va. RETERENCE CITED}

Adey, W. R., and Dunlop, C. W.i J. Frarmacol, and Exp. Forep. 130: 418. (1960).

Gronemoth, 4. 8. and Keall., I. 8. I J. Lab, Clla. Med, 31: 600, (1946).

Orolfonotoln, Y. E. DeVenlt, M., Tonhltake, J. and Cajowelt, J. E. : Arasth and Analy. 37: 283, (1958).

Hetterle, A. C. Woat, I. C. D Durbin, R. A. and Bryen, O. R.: I.

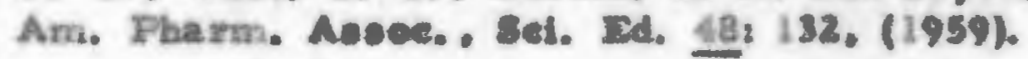

Lax, E. sunter, R., Pulle, I M, asd Chiron, A. E. : Anocthootelegy 20: 330, (1959).

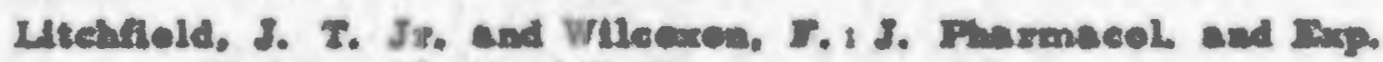
Therap 소 $99,(1949)$.

Laby, I. D. . Cohen, B. D. Rotenbanum, C. . Cotthob, J. 8. and Kolloy, R. I A. M. A. Arch. Nourel. Psychiat. 41: 363. (1959).

Moloon, R. M., Meneca, J., Mawwoll, G. . Nelson, J., Potere, Jt. an ktardy, R.: Li Extracorporeal Cireulation, J. G. Allen (oulow), Springlleld, IIl. Thomas, 1938, p. 459.

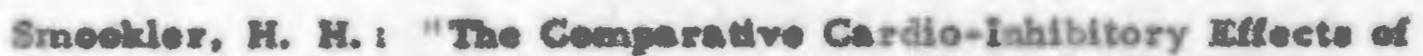
Substituted Cycloherranols" Unpeblished M.8. Theals, 1961: Univeralty of Rbode Ioland.

Smeallor, H. I., and De Feo, J. J.: J. Pharm, Set. 51: 736. (1963). 


\section{ACRNOWHADGHEMP}

The author would like to thank. Dr. John J. DeIreo for his guidance and assistance throughout this investigation. His help and encouragement have been a valuable aid. 